\title{
Neutron Diffraction Study of Hydrogen Thermoemission Phenomenon from Powder Crystals
}

\author{
I. Khidirov \\ Institute of Nuclear Physics, Uzbekistan Academy of Science \\ Uzbekistan
}

\section{Introduction}

In hydrogen energy powder metals or compounds that accumulate and desorb hydrogen extensively are used for hydrogen storages. Even in small quantities hydrogen can have stronger effect on structure and properties of some metals and compounds than heavier elements. Study of both hydrogen arrangement in crystal structure and process of its evacuation out of a lattice is of great importance for understanding the reasons and mechanisms of hydrogen influence on material properties. At vacuum hydrogen evacuation, it is possible to find such temperature $\mathrm{T}_{\mathrm{ev}}$ at which the hydrogen atoms, having low bond energy and high diffusion speed, are eliminated out of the lattice. The configuration of relatively heavy matrix atoms (previously stabilized by hydrogen atoms) does not change because of their insufficient diffusive mobility at this temperature. In this way it is possible to obtain new metastable phases artificially (hydrogen induced phases). In these phases the structure of initial hydrogenous phase can be kept (as if "frozen"), but during heat treatment they can undergo phase transitions uncharacteristic for the initial material. Vacuum removal of hydrogen out of a crystal lattice without change of symmetry is similar to thermoelectronic emission. Therefore we suggest the name of this new phenomenon as "hydrogen thermoemission" from crystals. Thus hydrogen thermoemission is complete removal of hydrogen atoms out of crystal structure without changing the crystal symmetry. The aim of this chapter is generalizing the results of neutron diffraction investigations of low-temperature hydrogen thermoemission phenomenon from powder crystals of Ti-N-H, $\mathrm{Zr}-\mathrm{N}-\mathrm{H}$, Ti-C-H, Ti-H systems and of rare earth metal trihydroxides $\mathrm{R}(\mathrm{OH})_{3}$, were $\mathrm{R}$ is $\mathrm{La}$, $\mathrm{Nd}$ or Pr. We will also look into formation of regularities and structural features of hydrogen induced phases.

\section{Experiment techniques}

\subsection{Choice of method of structural research}

Neutron diffraction method was chosen as the basic method of structure study which allows to obtain the largest and reliable information in the structural analysis of the alloys consisting of components (metals and hydrogen) with strongly differing order numbers. Neutron diffraction patterns were obtained using the neutron diffractometer mounted at the 
thermal column of the nuclear reactor of the Institute of Nuclear Physics of Uzbekistan Academy Sciences $(\lambda=0,1085 \mathrm{~nm})$ at room temperature. $X$-ray diffraction patterns were obtained using the $X$-ray diffractometer $\mathrm{DRON}-3 \mathrm{M}$ with $\mathrm{CuK}_{\alpha}-\operatorname{radiation}(\lambda=0.15418 \mathrm{~nm})$.

\subsection{Calculation methods of crystal structure determination}

The observed integral intensity $\mathrm{I}_{\mathrm{k}}(\mathrm{calc})=\mathrm{I}_{\mathrm{hkl}}$ of diffraction reflections from planes with Miller indexes h $\mathrm{k} l$ for a cylindrical sample is calculated using the formula (Bacon, 1975):

$$
\mathrm{I}_{\mathrm{hkl}}=\mathrm{I}_{0}\left(\lambda^{3} \mathrm{~h} / 2 \pi \mathrm{r}\right)\left(\mathrm{V} \rho / \rho^{\prime}\right)\left(\mathrm{p}_{\mathrm{hkl}} \mathrm{N}^{2} \mid \mathrm{F}(\mathrm{hkl})^{2} / \sin \theta \sin 2 \theta\right) \mathrm{A}_{\mathrm{hkl}} \exp (-2 \mathrm{~W}),
$$

where $\mathrm{I}_{0}\left(\lambda^{3} \mathrm{~h} / 2 \pi \mathrm{r}\right)\left(\mathrm{V} \rho / \rho^{\prime}\right)=\mathrm{k}$ is the constant dependent on geometry of the device and a sample; $\mathrm{p}_{\mathrm{hkl}}$ - the multiplicity factor ; $\mathrm{F}_{\mathrm{hkl}}{ }^{2}$ - the structural factor for reflection (h k l); $\mathrm{A}_{\mathrm{hkl}}$ - the factor of absorption (for the objects of our study the absorption factor is insignificant and, so, in calculations it was neglected), $r$ - distance from a sample up to the counter; $h$ - height of a crack of the counter; $\mathrm{N}$ - number of elementary cells in unit volume; $\mathrm{V}$ - volume of the studied sample; $\rho$ and $\rho^{\prime}$ - experimental and calculated density of the studied sample; $W$ the thermal factor which is determined by equation:

$$
\mathrm{W}=\left(8 \pi^{2} \overline{u^{2}} / 3\right) \sin ^{2} \theta / \lambda^{2},
$$

where $\overline{u^{2}}$ - atomic mean-square displacement. The structure factor $\mathrm{F}^{2}$ indicates the functional dependence of reflection intensities upon atom positions in the unit cell. This dependence is the function both of atom coordinates and Miller indexes of the reflex. The general formula of structure factor is:

$$
|F|^{2}=\left\{\sum_{n} b_{n} \cos 2 \pi\left(h x_{n}+k y_{n}+l z_{n}\right)\right\}^{2}+\left\{\sum_{n} b_{n} \sin 2 \pi\left(h x_{n}+k y_{n}+l z_{n}\right)\right\}^{2},
$$

where $x_{n}, y_{n}, z_{n}$ are atom coordinates expressed in fractional units of the corresponding parameter; $b_{n}$ - amplitude of neutron scattering on the atom nuclei. Summation is made over all atoms of the unit cell. Determination of the structure was carried out by "trial-and-error" method. The method consists in the next: the obtained experimental both angle positions and intensity of diffraction maxima are compared with the values calculated theoretically within the framework of the certain model. The most probable models of structure (taking into account X-ray data) were selected, and for each model the refinement of atom coordinates and position occupancy by least-square method of Rietveld (Rietveld, 1969) was carried out. At that, the refined parameters could be varied both together and separately. The model which yielded the best results (the minimal R-factor) was chosen. The structure model is correct if the experimental positions of maxima coincide with calculated ones and also if discrepancy indexes $\mathrm{R}$ are minimal. Last years for the refinement of crystal structures using X-ray and neutron diffraction data, full-profile method offered by Rietveld is widely used. The main point of this method is minimization of $R_{P}$ by means of full-profile processing of powder neutron diffraction data. At that, over the Bragg's reflections range the discrepancy indexes are calculated using both the full profile $\left(R_{P}\right)$ and weights of each point $\left(R_{W P}\right)$ and intensities of Bragg's reflections $\left(R_{B r}\right)$. Now there is the software package for 
calculation and refinement of crystal structures on the basis of this method. In the present work the software packages have been used DBW 3.2 (Young \& Wilas, 1982).

\subsection{Method of thermal treatment of samples}

Powder samples with grain sizes of $<60 \mu \mathrm{m}$ were studied. Dehydrogenation of hydrogenous compounds was carried out under persistent evacuation (at vacuum $<5.3 \times 10^{-3} \mathrm{~Pa}$ ). Thermal treatment of the samples under persistent evacuation was carried out in the vacuum furnace of SShVL-type. The principle scheme of this vacuum furnace is shown in Fig. 1. For carrying out annealing the sample (1) was placed in enclosed volume (2) on a spe-cial support (3). For vacuum control the vacuum-measuring block VIT-3 (4) and manometric lamps PMT-2 (5) and PMI-3 (6) were used. By means of mechanical (7) and diffusion (8) pumps in enclosed volume vacuum not worse than $5.3 \times 10^{-3} \mathrm{~Pa}$ was made. After that, vacuum heat treatment of a sample began: temperature was slowly raised since the room one up to necessary size with a step of $25^{\circ} \mathrm{C}$; a sample was exposed at each temperature at first during 24 and then during 36 and 48 hours. Temperature of a sample was controlled by potentiometer (9) with help of PPR (platinum - platinum-rhodium) thermocouple (10). Process was continued until the whole hydrogen leaves a sample. It should be noted that we observed vacuum to be not worse. If vacuum became insignificantly worse, temperature was decreased until vacuum was restored up to $5,3 \times 10^{-3}$ Pa. After annealing at each temperature with certain exposure time $(24,36$ and $48 \mathrm{~h}$.) neutron diffraction pattern was obtained. Hydrogen quantity in samples was determined as decline of incoherent background caused by incoherent neutron scattering on $\mathrm{H}$ nuclei. Since hydrogen nucleus has the largest amplitude of incoherent neutron scatting, its background scatting falls away with increase of Bragg angle (Bacon, 1975). The hydrogen content was by chemical analysis and controlled by the analysis of neutron structure data using the full-profile method of analysis intensities of neutron patterns (Young \& Wilas, 1982).

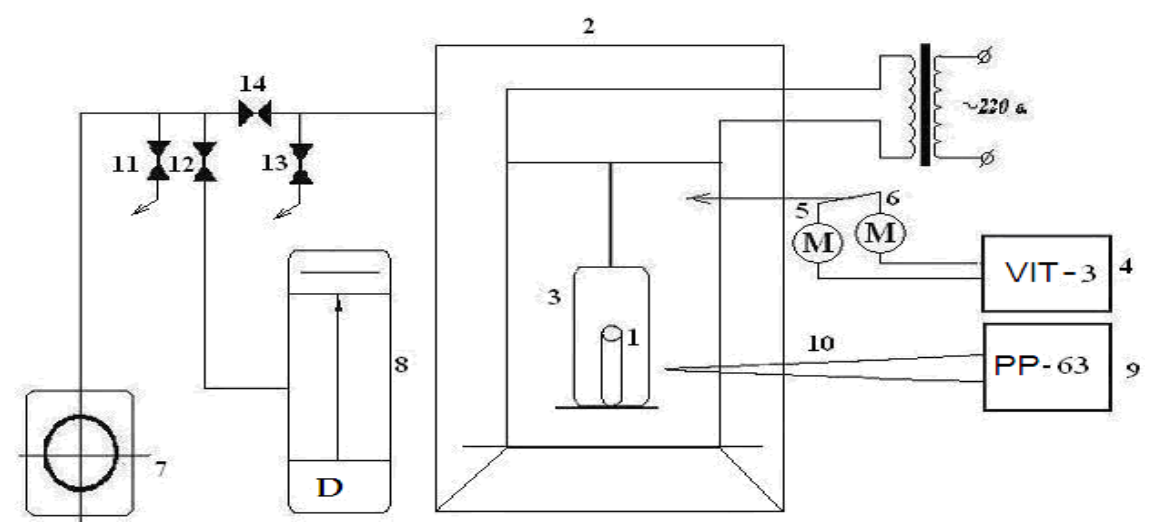

Fig. 1. The principle circuit of the high-temperature vacuum furnace of SShVL-type. 1powder sample in metal cassette; 2 - enclosed volume; 3 - support for mounting of a sample; 4- vacuum-measuring block VIT-3; 5-manometric lamp PMT-2 for measuring forevacuum; 6-manometric lamp PMI-3 for measuring high vacuum; 7-mechanical pump; 8- diffusion pump; 9-potentiometer PP-63; 10-thermocouple PPR; 11-, 12-, 13-, 14 - vacuum gates. 


\section{Results}

\subsection{Hydrogen thermoemission in the $\mathrm{Zr}-\mathrm{N}-\mathrm{H}$ system}

The solid solution $\mathrm{ZrN}_{0.43} \mathrm{H}_{0.38}$ for studying was prepared by self-propagating hightemperature synthesis. This method based on exothermal reaction of initial reagents. As initial materials nitrogen of the "extra pure" brand and $\mathrm{Zr}$ powder of the M-41 brand were taken. According to nameplate, the $\mathrm{Zr}$ powder contained 0.45 mas \% of hydrogen. The pressure of nitrogen in a constant pressure bomb was $7 \times 10^{7} \mathrm{~Pa}$. After synthesis the sample was exposed to homogenizing annealing in evacuated and sealed-off quartz ampoule at temperature $1000{ }^{\circ} \mathrm{C}$ during $12 \mathrm{~h}$. Then for fixation of the high-temperature state samples were hardened in air. Powder samples with grain sizes no more than $60 \mu \mathrm{m}$ were studied. Samples composition was determined by chemical analysis and was controlled by minimizing the $\mathrm{R}$ factors of structure determination using neutron diffraction patterns. Dehydrogenation of hydrogenous compounds was carried out under persistent evacuation (at vacuum not more than $5.3 \times 10^{-3} \mathrm{~Pa}$ ) (Khidirov et al., 2009). After dehydrogenating at every temperature a neutron diffraction pattern was surveyed. Hydrogen quantity in samples was watched as decline of incoherent background caused by incoherent neutron scattering on $\mathrm{H}$ nuclei. Since hydrogen nucleus has the largest amplitude of incoherent neutron scattering, its background scattering falls away with the increase of Bragg angle (Bacon, 1975). The hydrogen content was also estimated by the analysis of reflection intensities and sometimes by chemical analysis. As an initial sample the single-phase ordered solid solution $\mathrm{ZrN}_{0.43} \mathrm{H}_{0,38}$ was taken. According to X-ray structure analysis, the sample was single-phase and homogeneous and had hexagonal close-packed structure with unit cell parameters: $\mathrm{a}=0.3274 \pm 0.0002 ; \mathrm{c}=0.5321 \pm 0.0003 \mathrm{~nm} ; \mathrm{c} / \mathrm{a}=1.625$. The neutron diffraction pattern of the initial solid solution $\mathrm{ZrN}_{0,43} \mathrm{H}_{0,38}$ is shown in Fig. 2,a. Uniform slope of incoherent background points to hydrogen presence. The neutron diffraction data of the solid solution show that nitrogen atoms are ordered over one of two types of octahedral interstices alternating along $\mathrm{c}$ axis, and hydrogen atoms - over tetrahedral interstices of hexagonal close-packed (HCP) metal structure; unit cell parameters are: $a=0.3274 ; c=$ $0.5321 \mathrm{~nm}(c / a=1.625)$. The metal atoms $(\mathrm{zzr}=0.243)$ are displaced along $c$ axis from their ideal positions $\left(\mathrm{z}_{\mathrm{id}}=1 / 4\right)$ toward the plane of 1 (a) octahedrons occupied with nitrogen atoms (Table 1). So, the initial sample is the ordered solid solution of nitrogen and hydrogen in HCP structure of $\alpha-\mathrm{Zr}$ : it is $\alpha^{\prime}-\mathrm{Zr}_{2} \mathrm{~N}_{0.86} \mathrm{H}_{0.76}$ phase, space group $\mathrm{P} \overline{3} \mathrm{~m} 1$ structure of anti-CdI 2 type on nitrogen. Dehydrogenation of the $\alpha^{\prime}-\mathrm{Zr}_{2} \mathrm{~N}_{0.86} \mathrm{H}_{0.76}$ phase (of composition $\mathrm{ZrN}_{0.43} \mathrm{H}_{0.38}$ ) was carried out by a regime of step annealing within the temperature range $100{ }^{\circ} \mathrm{C} \leq \mathrm{T}<375^{\circ} \mathrm{C}$ with steps of $25^{\circ} \mathrm{C}$ and exposure time of $24-48 \mathrm{~h}$ at each temperature. Vacuum in the enclosed volume the vacuum was kept below $5.3 \times 10^{-3} \mathrm{~Pa}$ under permanent evacuation. After each vacuum annealing step, neutron diffraction pattern was obtained and quantity of hydrogen in a sample was estimated. Analysis of the neutron patterns shows that such dehydrogenation does not result in marked change of hydrogen content. Hydrogen content is confirmed by conservation of the slope of incoherent background in diffraction patterns. Though according to neutron structure analysis and vacuum extraction data dehydrogenation at $\mathrm{T} \geq 375^{\circ} \mathrm{C}$ during $36 \mathrm{~h}$ leads to practically complete hydrogen removal out of the sample (Fig. 2, b) while the quantity of nitrogen is kept. The structural analysis of the dehydrogenated sample showed that the ordered phase structure of anti-CdI $\mathrm{Cl}_{2}$ type $\left(\alpha^{\prime}-\mathrm{Zr}_{2} \mathrm{~N}_{0,86}\right)$ did not change. The phase was 


\begin{tabular}{|c|c|c|c|c|c|c|c|c|c|}
\hline \multirow{2}{*}{ Atom } & \multirow{2}{*}{ Position } & \multicolumn{4}{|c|}{ Atom coordinates } & \multirow{2}{*}{$\mathrm{B}, \mathrm{nm}^{2}$} & \multirow{2}{*}{$\Delta \mathrm{B}, \mathrm{nm}^{2}$} & \multirow{2}{*}{$\mathrm{n}$} & \multirow{2}{*}{$\Delta \mathrm{n}$} \\
\hline & & $x$ & $\mathrm{y}$ & z & $\Delta \mathrm{z}$ & & & & \\
\hline $\mathrm{Zr}$ & $2(\mathrm{~d})$ & $1 / 3$ & $2 / 3$ & 0.243 & 0.001 & 0.0039 & 0.0005 & 2 & \\
\hline $\mathrm{N}$ & 1 (a) & 0 & 0 & 0 & & 0.0072 & 0.0009 & 0.86 & 0.05 \\
\hline $\mathrm{H}$ & $2(\mathrm{~d})$ & $1 / 3$ & $2 / 3$ & 0.619 & 0.002 & 0.0107 & 0.0042 & 0.76 & 0.04 \\
\hline \multicolumn{10}{|c|}{$\mathrm{R}_{\mathrm{p}}=1.9 ; \mathrm{R}_{\mathrm{wp}}=2.5 ; \mathrm{R}_{\mathrm{Br}}=4.4 \%$} \\
\hline
\end{tabular}

Table 1. Structure characteristics and discrepancy indices $\mathrm{R}$ of the initial solid solution $\mathrm{ZrN}_{0.43} \mathrm{H}_{0.38}$ in the space group P $\overline{3} \mathrm{~m} 1$ Notice: $\mathrm{B}$ - individual thermal factor; $\mathrm{n}$ - occupancy of a position.

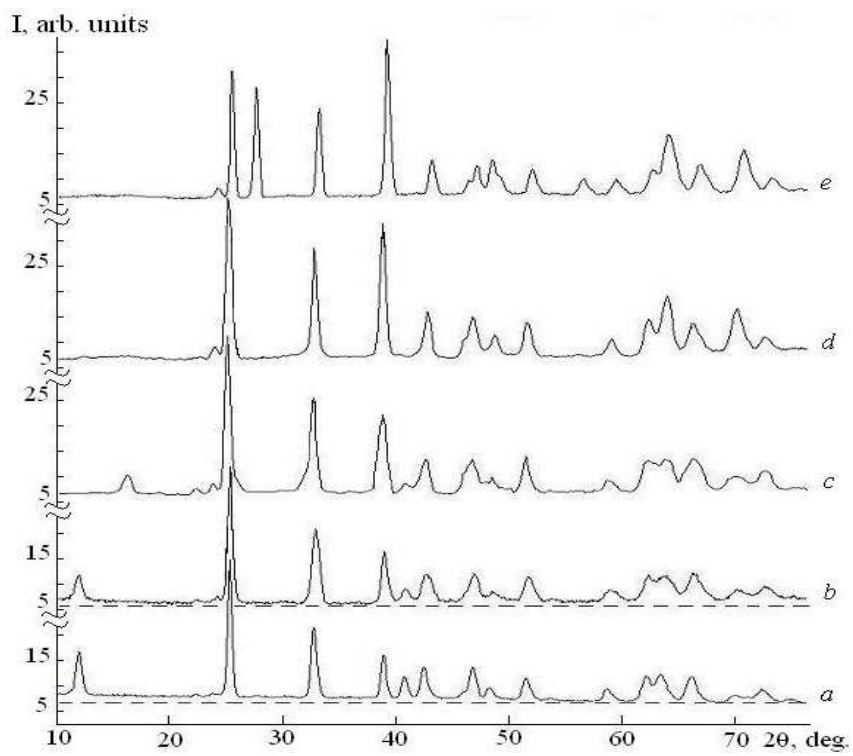

Fig. 2. Neutron diffraction patterns of solid solution: a $-\mathrm{Zr}_{2} \mathrm{~N}_{0.86} \mathrm{H}_{0.76}\left(\alpha^{\prime}\right.$; the space group $P \overline{3} m 1$ ); b - $\mathrm{Zr}_{2} \mathrm{~N}_{0.86}$ ( $\alpha^{\prime}$; the space group $P \overline{3} m 1$ ); $\mathrm{c}-\mathrm{Zr}_{2} \mathrm{~N}_{0,86}$ ( $\alpha^{\prime \prime}$; the space group Pnnm); $\mathrm{d}$ $\mathrm{ZrN}_{0,43}$ ( $\mathrm{L}_{3}^{\prime}$; the space group $\mathrm{P}_{3} / \mathrm{mmc}$ ); e -mixture of the $\alpha$ and $\delta$ phases.

annealed at $1000{ }^{\circ} \mathrm{C}$ for $3 \mathrm{~h}$ in evacuated and sealed quartz ampoule. As a result of annealing the dehydrogenated sample disintegrated into disordered solid solution of nitrogen in $\alpha-\mathrm{Zr}-$ hexagonal $\alpha$ phase (structure of $\mathrm{L}_{3}^{\prime}$ type) and a cubic $\delta$-phase (Fig.2e) corresponding to the equilibrium phase diagram of $\mathrm{Zr}-\mathrm{N}$ system (Gusev, 2001). It should be noted that the annealing of hydrogenous $\mathrm{Zr}_{2} \mathrm{~N}_{0,86} \mathrm{H}_{0,76}$ phase under similar conditions does not lead to decay or change of crystal structure. Further annealing of the disintegrated sample (mixture of $\alpha+\delta$

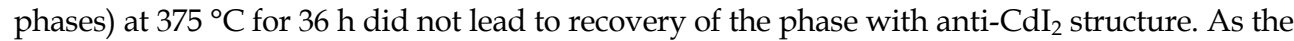
crystal structure of $\alpha^{\prime}-\mathrm{Zr}_{2} \mathrm{~N}_{0,86}$ phase has been stabilized by hydrogen (then all hydrogen atoms are removed) and it is not observed in the phase diagram, this phase is offered to name the hydrogen induced phase, unlike hydrogenous one. For the hydrogen induced phase $\alpha^{\prime}-$ $\mathrm{Zr}_{2} \mathrm{~N}_{0,86}$ the least value of divergence factor $\mathrm{R}_{\mathrm{Br}}=6.4 \%$ is obtained with nitrogen atoms 
arranged over $1(\mathrm{a})$ octahedral positions (space group $\mathrm{P} \overline{3} \mathrm{~m} 1$ ) with the free metal parameter $\mathrm{z}_{\mathrm{zr}}=0.255$ diffe-ring from the ideal value $\mathrm{z}_{\mathrm{id}}=1 / 4$ and from $\mathrm{z}=0.243$ for corresponding hydrogenous phase (Table 2). Hence, in the hydrogen induced phase metal atoms displacement directions change: from the plane filled with nitrogen atoms toward the plane of nitrogen vacancies (Fig. 3, $a$ and 3,b). Hydrogen induced phase $\alpha^{\prime}-Z_{2} \mathrm{~N}_{0,86}$ has the following lattice parameters: $a=0.3264 ; c=0.5299 \mathrm{~nm}(c / a=1.623)$. These values are less than those of corresponding hydrogenous phase. It should be noted that within the limits of experiment errors the axes relation $c / a$ is the same for the hydrogen induced phase and the hydrogenous phase. As a result of hydrogen removal out of hexag-onal lattice its near isotropic compression occurs. Analysis of neutron diffraction pattern of the phase $\mathrm{Zr}_{2} \mathrm{~N}_{0.86} \mathrm{H}_{0.76}$ dehydrogenated at 450-650 ${ }^{\circ} \mathrm{C}$ (Fig. 2,c) shows that at these tempera-tures the ordered orthorhombic $\mathrm{Zr}_{2} \mathrm{~N}_{0.86}$ phase with structure of anti- $\mathrm{CaCl}_{2}$ type ( $\alpha^{\prime \prime}$ phase) is formed. The diffraction pattern of this phase has been indexed in orthorhombic system (space group Pnnm) with the lattice parameters: $a=0.5632 \mathrm{~nm} \approx \sqrt{3} a_{\mathrm{o}}, b=0.5252 \mathrm{~nm} \approx c_{\mathrm{o}}, \mathrm{c}=0.3256 \mathrm{~nm} \approx a_{\mathrm{o}}$ where $a_{\mathrm{o}}$ and $c_{\mathrm{o}}$ are lattice parameters of the initial hexagonal phase. The unit cell of this phase is shown in Fig. 3,c. A good agreement between experimental and calculated intensities ( $R=6.3 \%)$ is achieved given that four $\mathrm{Zr}$ atoms are in positions $4(\mathrm{~g})$, the nitrogen atoms occupy mainly positions 2 (a) and partially - positions 2 (c) (Table 3). At $650{ }^{\circ} \mathrm{C}$ the partial disordering of nitrogen atoms $(\sim 20 \%)$, followed by their transition to octahedral interstices of another type -1 (c), takes place. In neutron diagram of the sample, dehydroge-nated at $800^{\circ} \mathrm{C}$, has been reflections from hexagonal phase with structure of $\mathrm{L}_{3}^{\prime}$ - type (a-phase) (Fig. 2, d). The unit cell of the $\alpha$ - phase is of anti - $\mathrm{CaCl}_{2}$ type ( $\alpha^{\prime \prime}$ - phase) is formed.

\begin{tabular}{|c|c|c|c|c|c|c|c|c|c|}
\hline \multirow{2}{*}{ Atom } & \multirow{2}{*}{ Position } & \multicolumn{4}{|c|}{ Atom coordinates } & \multirow{2}{*}{$\mathrm{B}, \mathrm{nm}^{2}$} & \multirow{2}{*}{$\Delta \mathrm{B}, \mathrm{nm}^{2}$} & \multirow{2}{*}{$\mathrm{n}$} & \multirow{2}{*}{$\Delta \mathrm{n}$} \\
\hline & & $x$ & $\mathrm{y}$ & $\mathrm{z}$ & $\Delta \mathrm{z}$ & & & & \\
\hline $\mathrm{Zr}$ & $2(d)$ & $1 / 3$ & $2 / 3$ & 0.254 & 0.002 & 0.0043 & 0.0008 & 2 & \\
\hline $\mathrm{N}$ & 1 (a) & 0 & 0 & 0 & & 0.0032 & 0.0012 & 0.86 & 0.01 \\
\hline
\end{tabular}

Table 2. Structure characteristics and discrepancy indices $\mathrm{R}$ of hydrogen induced phase $\mathrm{a}^{\prime}-$ $\mathrm{Zr}_{2} \mathrm{~N}_{0.86}$ (obtained at temperature $375^{\circ} \mathrm{C}$ ) in the space group $\mathrm{P} \overline{3} \mathrm{~m} 1$.

The diffraction pattern of this phase has been indexed in orthorhombic system (the space group Pnnm) with the lattice parameters: $a=0.5632 \mathrm{~nm} \approx a_{\mathrm{o}}, b=0.5252 \mathrm{~nm} \approx c_{\mathrm{o}}, \mathrm{c}=0.3256$ $\mathrm{nm} \approx a_{\mathrm{o}}$ where $a_{\mathrm{o}}$ and $c_{\mathrm{o}}$ are lattice parameters of the initial hexagonal phase. The unit cell of this phase is shown in Fig.3, c. A good agreement between experimental and calculated inten-sities $(R=6.3 \%)$ is achieved given that four $\mathrm{Zr}$ atoms are in positions $4(\mathrm{~g})$, nitrogen atoms occupy mainly positions 2 (a) and partially - positions 2 (c) (Table 3). At $650{ }^{\circ} \mathrm{C}$ the partial disordering of nitrogen atoms $(\sim 20 \%)$, followed by their transition to octahedral interstices of another type - 2 (c), takes place. In neutron diagram of the sample, dehydrogenated at $800{ }^{\circ} \mathrm{C}$, has been reflections from hexagonal phase with structure of $L_{3}^{\prime}$ type (a phase) (Fig. 2, d). The unit cell of the a-phase is shown in Fig. 3, d. We also investigated mutual transformation of the metastable phases. The annealing of the $\alpha^{\prime}$ hydrogen induced phase at temperatures $450-650{ }^{\circ} \mathrm{C}$ results in formation of $\alpha$ "phase. In 
other words, in this temperature range phase transition from $\alpha^{\prime}$ to $\alpha^{\prime \prime}$ is observed. The annealing of the $\alpha^{\prime \prime}$ phase at 400-375 ${ }^{\circ} \mathrm{C}$ during $36 \mathrm{~h}$ does not lead to restoration of $\alpha^{\prime}$ phase. Hence, $\alpha^{\prime} \stackrel{459^{\circ} \mathrm{C}}{\longrightarrow} \alpha^{\prime \prime}$ transition is monotropic (nonreversible) and $\alpha^{\prime}$ phase can be induced only by hydrogen thermoemission at temperature below that the temperature of $\alpha$ " phase formation. By increasing the temperature up to $750-800{ }^{\circ} \mathrm{C}$, the $\alpha^{\prime \prime}$ phase passes into $\alpha$-phase (disordered oversaturated solid solution of nitrogen in a lattice of $\alpha-\mathrm{Zr}$ ) with structure of $L_{3}^{\prime}$ type (Fig.2, d). This transition is enantiotropic (reversible) because the $\alpha$ "-phase is formed again by annealing the $\alpha-\mathrm{ZrN}_{0.43}$ phase at temperatures $650-450{ }^{\circ} \mathrm{C}$. The annealing of the phases at $1000{ }^{\circ} \mathrm{C}$ results in their disintegration into to $\alpha$ and $\delta$ phases (Fig. 2, e). No any annealing of samples that have been decayed into $\alpha$ and $\delta$ phases does not lead to formation of $\alpha^{\prime}, \alpha^{\prime \prime}$ and $\alpha$ phases in a single-phase kind. Therefore, the found phase transitions $\alpha^{\prime} \rightarrow \alpha^{\prime \prime} \rightarrow$ $\alpha^{\prime}$ occur in metastable state. The formed metastable phases and phase transitions between them are schematically shown in Fig. 4. Thus, by means of dehydroge-nation of the preliminary hydrogenated sample, three modifications of the oversaturated solid solution $\mathrm{ZrN}_{0.43}$ which do not exist in the equilibrium phase diagram have been obtained.
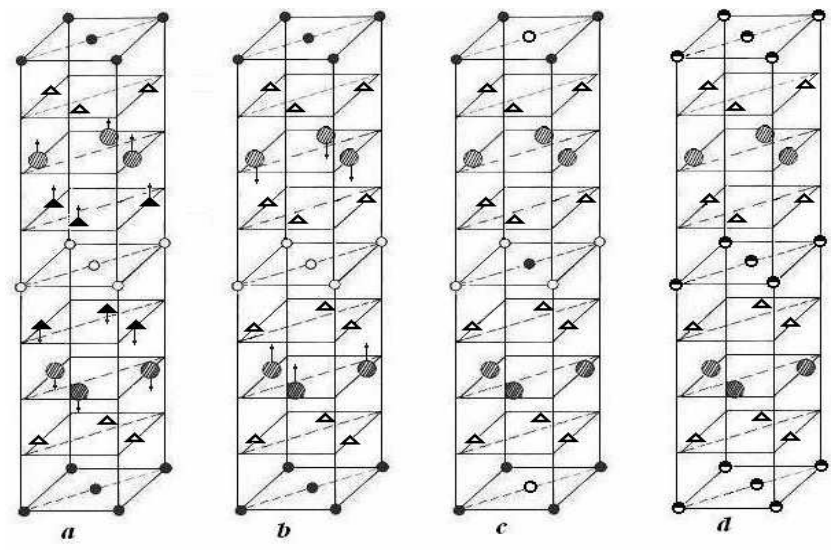

$$
0-1 \cdot-2 \quad 0-3 \Delta-4 \quad \Delta-5 \quad 0-6
$$

Fig. 3. Unit cells of the hydrogenous solid solution $\mathrm{ZrN}_{0.86} \mathrm{H}_{0.76}$ and of phases initiated by low-temperature vacuum extraction of hydrogen: 1-metal atoms; 2-nitrogen atoms; 3nitrogen vacancies; 4 -hydrogen atoms; 5 -hydrogen vacancies; 6 -statistic arrangement of nitrogen atoms.

\begin{tabular}{|c|c|c|c|c|c|c|c|c|c|c|}
\hline \multirow{2}{*}{ Atom } & \multirow{2}{*}{ Position } & \multicolumn{5}{|c|}{ Atom coordinates } & \multirow{2}{*}{$\mathrm{B}, \mathrm{nm}^{2}$} & \multirow{2}{*}{$\Delta \mathrm{B}, \mathrm{nm}^{2}$} & \multirow{2}{*}{$\mathrm{n}$} & \multirow{2}{*}{$\Delta \mathrm{n}$} \\
\hline & & $x$ & $\Delta \mathrm{x}$ & $\mathrm{y}$ & $\Delta \mathrm{y}$ & $\mathrm{z}$ & & & & \\
\hline $\mathrm{Zr}$ & $4(\mathrm{~g})$ & 0.324 & 0.002 & 0.271 & 0.001 & 0 & 0.39 & 0.06 & 4 & \\
\hline $\mathrm{N}$ & $2(\mathrm{a})$ & 0 & & 0 & & 0 & 0.53 & 0.13 & 1.38 & 0.02 \\
\hline $\mathrm{N}$ & $2(\mathrm{c})$ & 0 & & $1 / 2$ & & 0 & 0.53 & 0.13 & 0.34 & 0.02 \\
\hline \multicolumn{11}{|c|}{$\mathrm{R}_{\mathrm{p}}=4.5 ; \mathrm{R}_{\mathrm{wp}}=6.0 ; \mathrm{R}_{\mathrm{Br}}=6.7 \%$} \\
\hline
\end{tabular}

Table 3. Structure characteristics and discrepancy indices $\mathrm{R}$ of the $\alpha "-\mathrm{Zr}_{2} \mathrm{~N}_{0 .}$ 86 hydrogen induced phase in the space group Pnnm. 


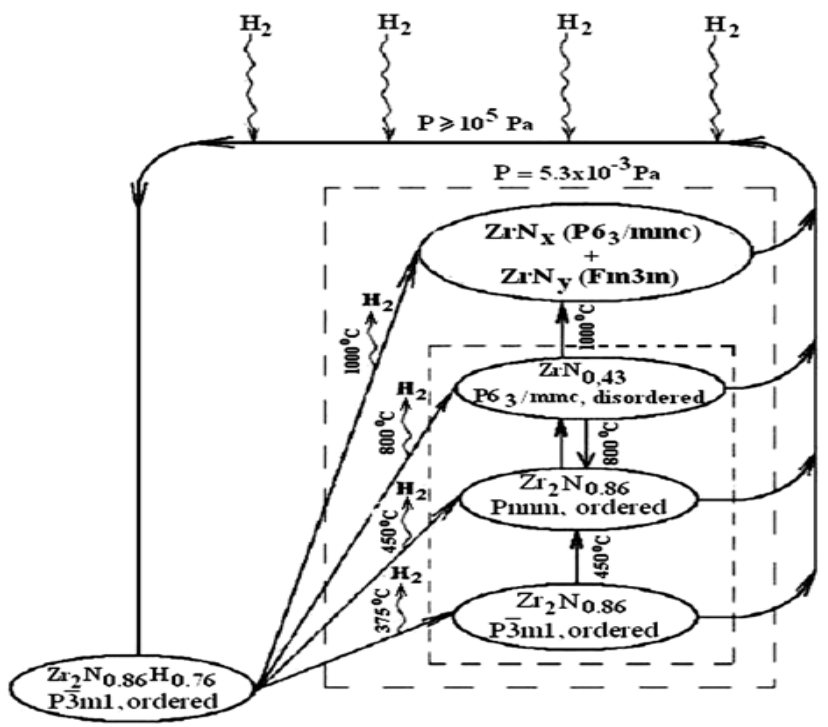

Fig. 4. Scheme of obtaining and phase transformations of metastable oversaturated solid solution in $\mathrm{Zr}-\mathrm{N}$ system.

In Fig. 4 these modifications are outlined by dashed lines (the small rectangle). Hydrogenation of solid solution of the Zr-N system (Gusev, 2001) reveals that under a hydrogen pressure of $\mathrm{P} \geq 10^{5} \mathrm{~Pa}$, all samples, including biphase ones, form the sol. s. $\alpha^{\prime}-\mathrm{Zr}_{2} \mathrm{~N}_{0.86} \mathrm{H}_{0.76}$ (space group $\mathrm{P} \overline{3} \mathrm{~m} 1$ ). This inverse process also is shown in Fig. 4. In these cases, the exposure time required for hydrogen saturation up to the concentration $\mathrm{H} / \mathrm{Zr}=0.38$ will be different at various temperatures. The scheme of reversible and nonreversible phase transformations in metastable state of the $\mathrm{ZrN}_{0.43}$ is shown in Fig. 5.

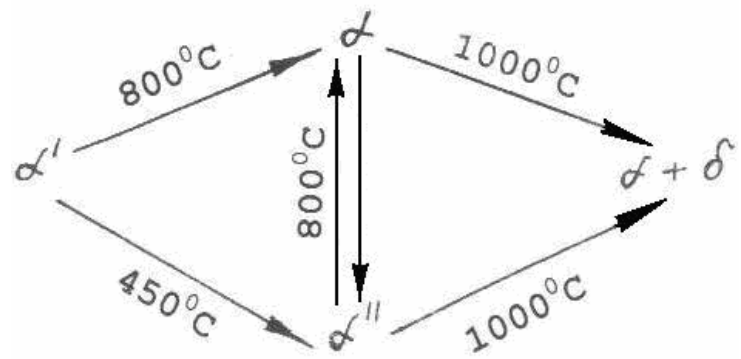

Fig. 5. Scheme of phase transformations on the basis of the hydrogen induced phase $\alpha^{\prime}-$ $\mathrm{Zr}_{2} \mathrm{~N}_{0.86 \text {. }}$

\subsection{Hydrogen thermoemission in $\mathrm{Ti}-\mathrm{N}(\mathrm{C})-\mathrm{H}$ systems}

Low-temperature vacuum evacuation of hydrogen has been investigated in the ordered solid solution $\alpha^{\prime}-\mathrm{Ti}_{2} \mathrm{~N}_{0.52} \mathrm{H}_{0.30}$ (space group $\mathrm{P} 3 \mathrm{~m} 1$ ) and the disordered solid solution 


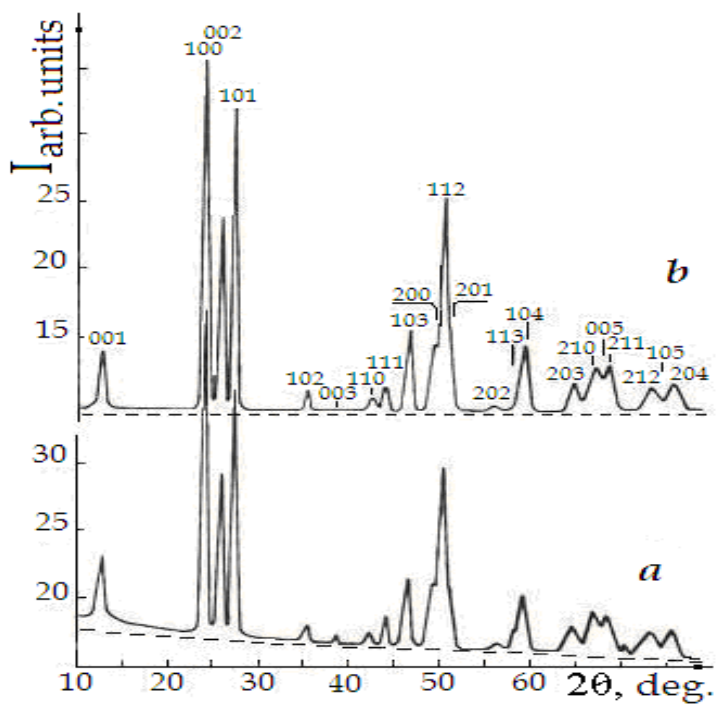

Fig. 6. Neutron diffraction patterns of the $\alpha^{\prime}-\mathrm{Ti}_{2} \mathrm{~N}_{0.52} \mathrm{H}_{0.30}$ phase (a) and the $\alpha^{\prime}-\mathrm{Ti}_{2} \mathrm{~N}_{0.52}$ hydrogen induced phase (b).

$\alpha-\mathrm{TiN}_{0.26} \mathrm{H}_{0.15}$ (space group $\mathrm{P}_{3} / \mathrm{mmc}$ ) (Khidirov et al. 1991). In Fig.6, $a$, the neutron diffractogram of the ordered solid solution $\alpha^{\prime}-\mathrm{Ti}_{2} \mathrm{~N}_{0.52} \mathrm{H}_{0.30}$ is shown. A declining incoherent background is evident. After vacuum annealing at $370{ }^{\circ} \mathrm{C}$ this background disappears (Fig. $6, b)$. This provides evidence for the removal of hydrogen from the lattice, findings are confirmed by chemical analysis. As in the neutron pattern (Fig. 6, $b$ ), all selective reflections are the same. The ordered structure of the solid solution has not changed. In this way, the "frozen" hydrogen-free metastable phase of Ti-N system - the hydrogen induced $\alpha^{\prime}-\mathrm{Ti}_{2} \mathrm{~N}_{0.52}$ phase is obtained. Processing the neutron data by Rietveld method has shown that the value of the free metal parameter $\mathrm{z}$ changes in the formed hydrogen induced phase. It changes from $z=0.237$ - for the hydrogenous solid solution (that is less than $z=1 / 4$ for the ideal position) to $z=0.260-$ for the hydrogen induced phase (i.e. greater than $z$ ideal). Annealing the obtained phase in an evacuated and sealed quartz ampoule at $\mathrm{T}>370{ }^{\circ} \mathrm{C}$ results in decay corresponding to the equilibrium phase diagram of the Ti-N system (Gusev, 2001). Lowtemperature vacuum evacuation of hydrogen was also studied in solid soluti-ons $\mathrm{TiC}_{0,45} \mathrm{H}_{0,90}, \mathrm{TiC}_{0,45} \mathrm{H}_{0,64}$, and $\mathrm{TiC}_{0.35} \mathrm{H}_{0.43}$ (Khidirov et al., 2008). In the neutron patterns of the initial solid solutions (Fig. 7), superstructure reflections are visible together with structural reflections and they are indexed within space group $\mathrm{P} \overline{3} \mathrm{~m} 1$. According to neu-tron structure analysis of the investigated solid solutions, thermoemission of $\mathrm{H}$ is virtu-ally not observed up to $250^{\circ} \mathrm{C}$. In solid solutions with a large carbon concentration, the separation of pure titanium and face-centered cubic phase (most probably carbohydride $\mathrm{TiC}_{\mathrm{x}} \mathrm{H}_{\mathrm{y}}$ ) was found above $275^{\circ} \mathrm{C}$. By further increasing the temperature, the quantity of precipitate phases increases; up to $400^{\circ} \mathrm{C}$, the incoherent background slope is kept constant. Thus, solid solutions with high concentration of carbon (and hydrogen) $-\mathrm{TiC}_{0,45} \mathrm{H}_{0,90}, \mathrm{TiC}_{0,45} \mathrm{H}_{0,64}$, are thermostable in vacuum only at temperatures $\mathrm{T}<275^{\circ} \mathrm{C}$, and in $\mathrm{HCP}$ and face-centered 
cubic (FCC) phases hydrogen remains up to $400^{\circ} \mathrm{C}$. In the neutron diagram of the solid solution $\mathrm{TiC}_{0,35} \mathrm{H}_{0,43}\left(\alpha^{\prime}-\mathrm{Ti}_{2} \mathrm{C}_{0.70} \mathrm{H}_{0.86}\right)$ after vacuum annealing at $275^{\circ} \mathrm{C}$, there are the same reflections which have been observed in the neutron pattern of the initial hydrogenous sample (Fig. 8); incoherent background, however, is completely absent.

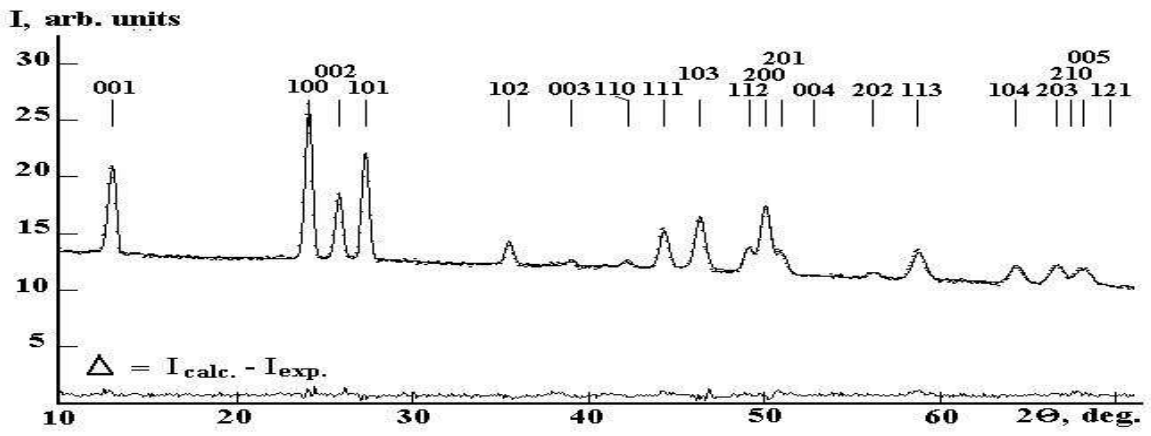

Fig. 7. Neutron diffraction patterns of the $\alpha^{\prime}-\mathrm{Ti}_{2} \mathrm{C}_{0.70} \mathrm{H}_{0.86}$ - phase: solid line - calculated, dots - experimental, $\Delta$ - differential one. Miller indices are indicated above the reflections.

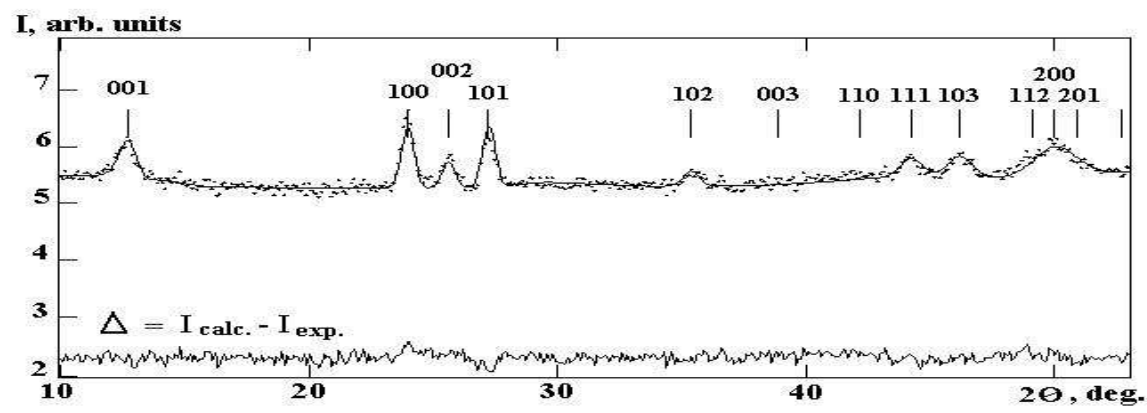

Fig. 8. Neutron diffraction patterns of the ordered $\alpha^{\prime}-\mathrm{Ti}_{2} \mathrm{C}_{0.70}-$ phase. The notations are the same as in Fig. 7. Calculated diagram was obtained in sp. gr. $\mathrm{P} \overline{3} \mathrm{~m} 1$ with $\mathrm{z}_{\mathrm{Ti}}=0.305$ however, is completely absent.

Analysis of the diffraction compositions corresponds to the formula $\mathrm{TiC}_{0,35}$. The initial ordered structure, however, remains unaltered. Therefore, hydrogen thermoemission at $275^{\circ} \mathrm{C}$ results in the formation of hexagonal ordered $\alpha^{\prime}-\mathrm{Ti}_{2} \mathrm{C}_{0.70}$ - phase in a metastable state. Analysis of the diffraction pattern by the Rietveld method proved a lack of hydrogen and showed that the sample composition corresponds to the formula $\mathrm{TiC}_{0,35}$. The initial ordered structure, however, remains unaltered. Therefore, hydrogen thermoemission at $275^{\circ} \mathrm{C}$ results in formation of the hexagonal ordered $\alpha^{\prime}-\mathrm{Ti}_{2} \mathrm{C}_{0.70}$ - phase in a metastable state. It is necessary to note the large errors in the determination of lattice parameters and the high value of divergence factors $\left(\mathrm{R}_{\mathrm{Br}}=13,6 \%\right)$. Evidently, these results are caused by the distortion of peak forms and wide scatter of points in the neutron diffraction pattern; this is because of strong static distortions of the lattice. The large errors do not allow comparison of the lattice parameters of hydrogen induced phase $\mathrm{Ti}_{2} \mathrm{C}_{0.70}$ and the initial hydrogenous phase. 
In the hydrogen induced $\alpha^{\prime}-\mathrm{Ti}_{2} \mathrm{C}_{0.70}$ phase the sign of metal atoms displacement $\left(\mathrm{z}_{\mathrm{Ti}}=0,305\right)$ relative to the ideal position $\left(\mathrm{z}_{\mathrm{id}}=1 / 4\right)$ changes in comparison with the hydrogenous $\alpha^{\prime}-$ $\mathrm{Ti}_{2} \mathrm{C}_{0.70} \mathrm{H}_{0.86}$ phase $\left(\mathrm{z}_{\mathrm{Ti}}=0,237\right)$. If the value of $\mathrm{z}_{\mathrm{Ti}}$ in the hydrogen induced phase $\mathrm{Ti}_{2} \mathrm{C}_{0.70}$ is assumed to be the same as in the hydrogenous phase $\alpha^{\prime}-\mathrm{Ti}_{2} \mathrm{C}_{0.70} \mathrm{H}_{0.86}$, an essential growth of $\mathrm{R}_{\mathrm{Br}}$ is also observed (up to $30 \%$ at $\mathrm{z}_{\mathrm{Ti}}=0.250$ and $33 \%$ at $\mathrm{z}_{\mathrm{Ti}}=0.237$ ). Thus, in the hydrogeninduced $\alpha^{\prime}-\mathrm{Ti}_{2} \mathrm{C}_{0.70}$-phase, just as in the hydrogen induced $\alpha^{\prime}-\mathrm{Ti}_{2} \mathrm{~N}_{0.52}$ phase (Khidirov et al., 1991), the sign of metal atoms displacement relative to their ideal position changes in comparison with corresponding hydrogen-containing phases. As a result of this research, it can be concluded that in solid solutions of the Ti-C(N)-H system, complete thermoemission of hydrogen with a conservation of initial symmetry (caused by hydrogen) is observed in strongly defective structures. Apparently, in strongly defective solid solutions the interaction forces between atoms are weakened, and the temperature of hydrogen evacuation $\left(\mathrm{T}_{\mathrm{ev}}\right)$ is below that of redistribution of interstitial atoms or of recrystallization $\left(\mathrm{T}_{\text {recr }}\right): \mathrm{T}_{\mathrm{ev}}<\mathrm{T}_{\text {recr }}$.

\section{Neutron diffraction study of tryhydroxides rare-earth metals $\mathrm{R}(\mathrm{OH})_{3}$ and metasable crystals of trioxides of rare-earth metals $\left.\mathrm{R}_{[} \mathrm{O}_{3}\right](\mathrm{R}$ is $\mathrm{La}, \mathrm{Pr}$ or $\mathrm{Nd}$ )}

\subsection{Neutron diffraction study of initials samples of tryhydroxides $\mathrm{R}(\mathrm{OH})_{3}$}

The investigated samples were obtained as a result of oxidation in air of the corresponding rare earth metal having 99,95\% purity. The X-Ray phase analyses showed that the samples contained mainly the trihydroxide of the rare earth metal which is consistent with the results of other authors (Portnoy, Timofeeva, 1986). For example, the neutron diffraction pattern of $\operatorname{Pr}(\mathrm{OH})_{3}$ is represented in Fig. 9, a). The steep slope of the background is caused

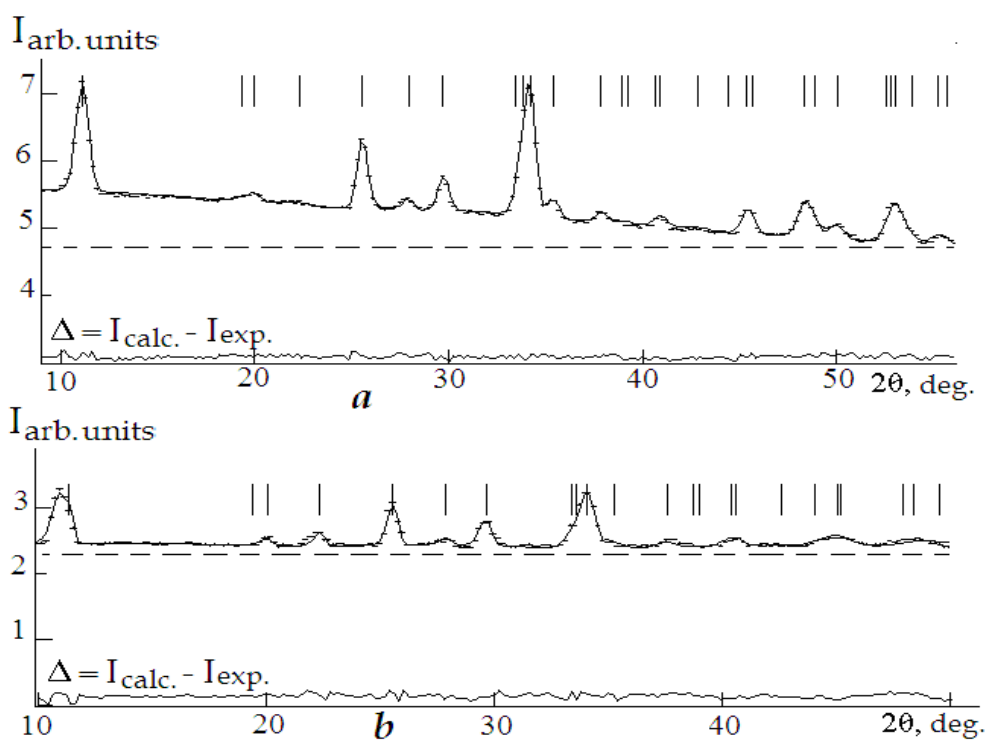

Fig. 9. Neutron diffraction patterns of the $\operatorname{Pr}(\mathrm{OH})_{3}$ and the $\operatorname{Pr}\left[\mathrm{O}_{3}\right]$ (space group $\mathrm{P}_{3} / \mathrm{m}$ ). The notations are the same as in Fig. 7. 
of neutrons by hydrogen nuclei (Bacon, 1975). Diffraction patterns of other trihydroxides were similar. All rare earth metals from trihydroxides $\mathrm{R}(\mathrm{OH})_{3}(\mathrm{R}=\mathrm{La}$ to $\mathrm{Yb})$ having $\mathrm{UCl}_{3}-$ type hexagonal structure (Portnoy, Timofeeva, 1986). The structure can be described in $\mathrm{P}_{3} / \mathrm{m}$ space group, where the rare earth element atoms $\mathrm{R}$ occupy $2(\mathrm{~d})$ positions and $(\mathrm{OH})$ complexes occupy $6(\mathrm{k})$ positions having free parameters $x=0.29, y=0.38$ (Schubert, 1971). The crystal structure of $\mathrm{R}(\mathrm{OH})_{3}$ phases was studied by X-ray diffraction. It was difficult to determine the hydrogen atom coordinates using the X-ray method, because the scattering amplitude of hydrogen atoms is much less than that for rare earth metals. That is why the coordinates of the spherical anions $(\mathrm{OH})^{-}$were ascribed to the hydrogen atoms. It seemed reasonable to try to determine the coordinates of hydrogen atoms using neutron diffraction because in case of neutrons the scattering amplitude of hydrogen nuclei $\left(b_{\mathrm{H}}=-0.374 \times 10^{-3}\right.$ $\mathrm{nm})$ is comparable with that for rare earth metals $\left(b_{\mathrm{La}}=0.83 \times 10^{-3} \mathrm{~nm}, \mathrm{~b}_{\mathrm{Pr}}=0.44 \times 10^{-3} \mathrm{~nm}\right.$, $b_{\mathrm{Nd}}=0.72 \times 10^{-3} \mathrm{~nm}$ ) (Bacon, 1975). The coordinates of hydrogen atoms in rare earth metal trihydroxides $\mathrm{R}(\mathrm{OH})_{3}(\mathrm{R}$ is $\mathrm{La}, \mathrm{Pr}, \mathrm{Nd})$ were determined using the neutron diffraction method (Khidirov \& Om, 1991). All diffraction peaks in the neutron diagrams could be indexed in the hexagonal unit cell with the lattice parameters which are given in Table 4.

\begin{tabular}{|c|c|c|c|}
\hline Sample & $a(\mathrm{~nm})$ & $c(\mathrm{~nm})$ & $c / a$ \\
\hline $\mathrm{La}(\mathrm{OH})_{3}$ & $0.6529 \pm 0.0006$ & $0.3852 \pm 0.0003$ & $0.5895 \pm 0.0003$ \\
\hline $\mathrm{Pr}(\mathrm{OH})_{3}$ & $0.6458 \pm 0.0005$ & $0.3771 \pm 0.0002$ & $0.5837 \pm 0.0004$ \\
\hline $\mathrm{Nd}(\mathrm{OH})_{3}$ & $0.6437 \pm 0.0005$ & $0.3747 \pm 0.0002$ & $0.5821 \pm 0.0004$ \\
\hline
\end{tabular}

Table 4. The lattice parameters of $\mathrm{R}(\mathrm{OH})_{3}$.

\begin{tabular}{|c|c|c|c|c|}
\hline Atom & Position & $\mathrm{x}$ & $\mathrm{y}$ & $\mathrm{z}$ \\
\hline $2 \mathrm{R}$ & $2(\mathrm{~d})$ & $1 / 3$ & $2 / 3$ & $1 / 4$ \\
\hline $6 \mathrm{O}$ & $6(\mathrm{k})$ & $0.30 \pm 0.002$ & $0.385 \pm 0.002$ & $1 / 4$ \\
\hline $6 \mathrm{H}$ & $6(\mathrm{k})$ & $0.16 \pm 0.003$ & $0.288 \pm 0.004$ & $1 / 4$ \\
\hline
\end{tabular}

Table 5. Structure characteristics of $\mathrm{R}(\mathrm{OH})_{3}$ in the space group $\mathrm{P}_{3} / \mathrm{m}$.

\begin{tabular}{|c|c|c|c|}
\hline Sample & $\mathrm{R}_{\mathrm{p}}, \%$ & $\mathrm{R}_{\mathrm{wp}}, \%$ & $\mathrm{R}_{\mathrm{Br}}, \%$ \\
\hline $\mathrm{La}(\mathrm{OH})_{3}$ & 0.74 & 0.93 & 6.59 \\
\hline $\mathrm{Pr}(\mathrm{OH})_{3}$ & 0.54 & 0.72 & 7.01 \\
\hline $\mathrm{Nd}(\mathrm{OH})_{3}$ & 0.88 & 1.03 & 7.32 \\
\hline
\end{tabular}

Table 6. R-factors for $\mathrm{R}(\mathrm{OH})_{3}$ in the $\mathrm{P}_{3} / \mathrm{m}$ space group.

The lattice parameters are close to those obtained by other authors (Portnoy \& Timofeeva, 1986)] except $\mathrm{c}$ of $\mathrm{Nd}(\mathrm{OH})_{3}$. A decrease in the ratio $\mathrm{c} / \mathrm{a}$ with increasing metal atom number corresponds to the reduction of atomic radius in line of the $\mathrm{La}-\mathrm{Pr}-\mathrm{Nd}$. The least $\mathrm{R}-$ factor was obtained for the model in the $\mathrm{P}_{3} / \mathrm{m}$ space group (Table 5). For the investigated samples this model yielded, the following $\mathrm{R}$ - factors are given in Table 6 . The $\mathrm{R}$-factor values can be takes into account the high background level of the neutron diffraction patterns caused by incoherent scattering of the hydrogen nuclei and thermal diffusion scattering. The distance between the oxygen and hydrogen atoms in the $\mathrm{O}-\mathrm{H}$ pairs equals $(0.082 \pm 0.007) \mathrm{nm}$. A difference curve (observed minus calculated) is shown in Fig. 9, a. It should be noted that if the same coordinates are formally ascribed to the oxygen and 
hydrogen atoms the $\mathrm{R}$ - factor increases considerably. For example, for $\mathrm{La}(\mathrm{OH})_{3} \mathrm{R}_{\mathrm{Br}}=35.7 \%$. Thus, our results show that, though hydrogen and oxygen atoms occupy the same positions $6(\mathrm{k})$, their coordinates differ.The unit cell of $\mathrm{R}(\mathrm{OH})_{3}$ is shown in Fig. 10. Oxygen and hydrogen atoms form dumb-bells oriented as is the oxygen atom is attracted and the hydrogen atom is repelled by the nearest metal atoms.

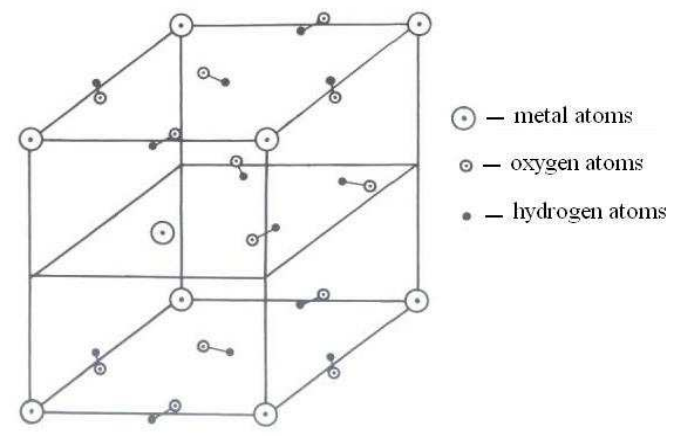

Fig. 10. The unit cell of $\mathrm{R}(\mathrm{OH})_{3}$.

\subsection{Neutron diffraction study of hydrogen thermoemission from crystals of tryhydroxides rare-earth metals $\mathrm{R}(\mathrm{OH})_{3}$}

For rare-earth metal trihydrooxides $\mathrm{R}(\mathrm{OH})_{3}$ three characteristic temperatures are observed for hydrogen extraction at continuously pumped out high vacuum.

1. The temperature of practically complete hydrogen evacuation from the lattice without change in symmetry of crystal - $\mathrm{T}_{\mathrm{evac}}\left(140-150^{\circ} \mathrm{C}\right)$, at which the crystal structure does not change, but is significantly deformed (Fig. 9, $b$ ). Neutron diffraction calculation of samples after dehydrogenation at $130-150{ }^{\circ} \mathrm{C}$ by means of full-profile Rietveld analysis demonstrates no hydrogen in the sample, though the crystal structure is conserved (Fig. 9, b). Significant decrease of diffraction refraction intensities shown by neutron diffraction analysis after vacuum dehydrogenation can be explained, first of all, by lack of hydrogen atoms in lattice; secondly, by lower gross number of dehydrogenated samples. The latter is related to the fact that for acceleration of the process of hydrogen separation from powder $R(O H)_{3}$ the quantity of samples was taken three times less than that taken for the original powders of $\mathrm{R}(\mathrm{OH})_{3}$. After hydrogen removal one can observe widening of half-width and distortion of diffraction peaks form, which is caused by pronounced deformations in crystal lattice after hydrogen removal. The best agreement between experimental and calculated intensities of neutron-diffraction reflections (Fig. 9, b) and minimal errors in structure determination (R) can be obtained only assumed that these compounds are "trioxides" containing $\mathrm{R}\left[\mathrm{O}_{3}\right]$. It is worth of mentioning that the temperature of hydrogen evacuation from lattice in all trioxides $\mathrm{R}(\mathrm{OH})_{3}$ within errors in temperature determination $(\Delta \mathrm{T}= \pm 12 \mathrm{C})$ is almost the same. This can be explained by the fact that rare-earth metals La, Pr and Nd have similar valence electron shells and does not differ in sizes of atoms, where as trihydrooxides $\mathrm{R}(\mathrm{OH})_{3}$ have isomorphic structure. The results of neutron diffraction analysis calculations $\operatorname{Pr}[\mathrm{O}]_{3}$ within space group $\mathrm{P}_{3} / \mathrm{m}$ are presented in Table 7 (Khidirov, 2011). One should notice large errors in determination of lattice parameters and large value of $\mathrm{R}_{\mathrm{Br} \text {. }}$. It is apparently caused by 
distortion of peaks forms due to strong statistical lattice deformations appearing after hydrogen removal. Formation of such a compound in $\mathrm{R}$ - $\mathrm{O}$ systems contradicts to the valence conservation principle. Oxygen is double-valence, and rare-earth metals can be either three or four-valence. But all of them in $\operatorname{Rr}(\mathrm{OH})_{3}$ are three-valence. It is obvious that "trioxides" $\mathrm{R}\left[\mathrm{O}_{3}\right]$ have broken bonds and unpaired electrons, likewise that of radicals, that is they have excessive negative charge: $\mathrm{R}^{3+}\left[\mathrm{O}_{3}\right]^{6-}$. This material can be stable only at relatively low temperatures and in medium free of hydrogen. Indeed, annealing of $\mathrm{R}\left[\mathrm{O}_{3}\right]$ or dehydrogenation of $\mathrm{R}(\mathrm{OH})_{3}$ at temperatures of $150{ }^{\circ} \mathrm{C}$ longer that 24 hours leads to its amorphisation, which is pointed by lack of selective diffraction reflections in neutron diffraction analysis, and formation of small diffuse reflection at angles of $2 \theta=28-38$ degrees. Similar phenomenon takes place at even slight increase of temperature (up to $180{ }^{\circ} \mathrm{C}$ ). Obtained "trioxide" $\mathrm{R}\left[\mathrm{O}_{3}\right]$ due to its valence instability "tends" to trap three more protons. This can be accomplished by trapping in lattice of three hydrogen ions at first instance. Therefore, metastable "trioxides" in atmosphere, apparently, interact with water molecules, and retransform step by step back in the trihydrooxide $\mathrm{R}(\mathrm{OH})_{3}$, by compensating the excessive negative charge by three hydrogen atoms. This is demonstrated by the neutron diffraction analysis calculations $\mathrm{R}\left[\mathrm{O}_{3}\right]$, taken in 30 days after obtaining neutron diffraction patters and by repeated formation of incoherent background on the neutron diffraction patterns. In other words, the neutron diffraction patterns of $\mathrm{R}\left[\mathrm{O}_{3}\right]$ samples after exposition in atmosphere at temperatures 285 - $290 \mathrm{~K}$ (temperature in the reactor hall in winter) within 30 days are both qualitatively and quantitatively become identical to the corresponding neutron diffraction analysis patterns for $\mathrm{R}(\mathrm{OH})_{3}$. Hence, one can conclude that in atmosphere the «trioxide» $\mathrm{R}\left[\mathrm{O}_{3}\right]$ «self-cures» until complete restoration of the trihydrooxides of rare earth metals $\mathrm{R}(\mathrm{OH})_{3}$. (Obviously, the reaction rate depends on temperature). Since the hydrogen concentration on Earth's surface is rather low, one can assume that $\mathrm{R}[\mathrm{O}]_{3}$ captures hydrogen, mainly from, water vapor in the air, leaving oxygen molecules free:

$$
4 \mathrm{R}^{3+}[\mathrm{O}]_{3}{ }^{6-}(\text { powder metastable crystal })+6 \mathrm{H}_{2} \mathrm{O}=4 \mathrm{R}(\mathrm{OH})_{3}(\text { powder stable crystal }) \rightarrow 3 \mathrm{O}_{2} \uparrow
$$

\begin{tabular}{|c|c|c|c|c|c|}
\hline Atom & Number & Pozition & $\mathrm{X}$ & $\mathrm{y}$ & $\mathrm{z}$ \\
\hline $\mathrm{Pr}$ & 2 & $2(\mathrm{~d})$ & $2 / 3$ & $1 / 3$ & $1 / 4$ \\
\hline $\mathrm{O}$ & 6 & $6(\mathrm{k})$ & $0.376 \pm 0.002$ & $0.461 \pm 0.002$ & $1 / 4$ \\
\hline \multicolumn{6}{|c|}{$a=0.658 \pm 0.018 \mathrm{HM} ; c=0.381 \pm 0.006 \mathrm{HM} ; \mathrm{R}=0.60 \% ; \mathrm{R}=0.81 \% ; \mathrm{R}=13,7 \%$} \\
\hline
\end{tabular}

Table 7. Structural characteristics and R-factors of the "trioxide" $\operatorname{Pr}\left[\mathrm{O}_{3}\right]$ the model in the $6_{3} / \mathrm{m}$ space group.

Therefore, «trioxide» $\mathrm{R}\left[\mathrm{O}_{3}\right]$ in atmosphere can simultaneously be a hydrogen absorber and oxygen generator. Separation (by low-temperature removal) of hydrogen from $4 \mathrm{R}(\mathrm{OH})_{3}$ can again lead to restoration of its capabilities to be a simultaneous hydrogen accumulator and oxygen generator in a medium containing water molecules. The cycle described above can be accomplished many times. It is shown in Fig. 11.

2. Amorphisation temperature- $\mathrm{T}_{\text {amorph. }}\left(180^{\circ} \mathrm{C}\right)$, at which the selective diffraction reflection disappear completely and diffuse reflection appear in the neutron diffraction pattern (Fig. 12). The experiments revealed that amorphous $\mathrm{R}\left[\mathrm{O}_{3}\right]$ in atmosphere crystallize spontaneously and transform into trihydrooxides of corresponding rare-earth metals in 1-1.5 
months at the temperature of the reactor's hall in winter $\left(15-20{ }^{\circ} \mathrm{C}\right)$. It was interesting to study the kinetics of this process. We therefore periodically generated the neutron diffraction patters of amorphous $\left.\mathrm{La}_{0} \mathrm{O}_{3}\right]$ (Fig. 13). During this process, the measured sample was located continuously in the $6 \mathrm{~mm}$ in diameter vanadium cylinder with an open cap. Fig. 13 shows some peculiar neutron diffraction patterns taken within 50 days.

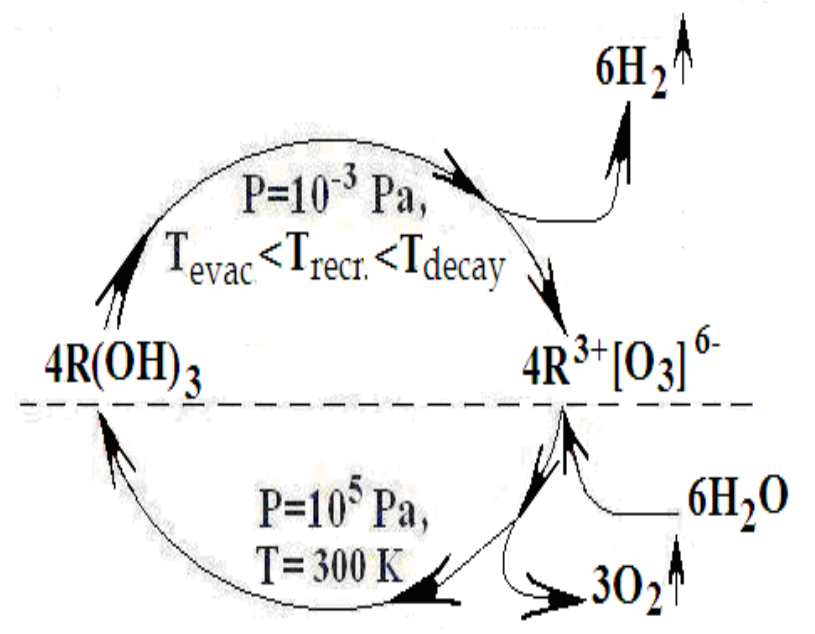

Fig. 11. The scheme of a cycle of reception «trioxides» $\mathrm{R}\left[\mathrm{O}_{3}\right]$ from $\mathrm{R}(\mathrm{OH})_{3}$ in continuously pumped out high vacuum and repeated formation $\mathrm{R}(\mathrm{OH})_{3}$ from «try-oxides» $\mathrm{R}\left[\mathrm{O}_{3}\right]$ by selfcuring in atmospheric conditions.

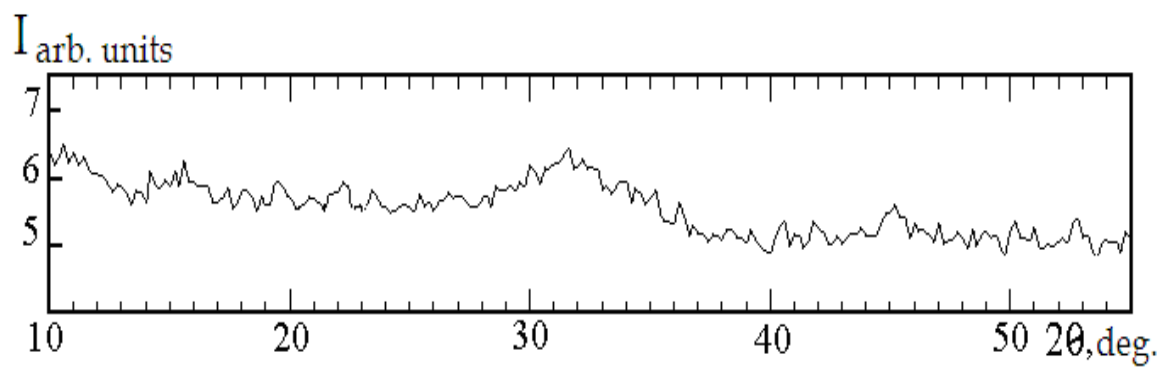

Fig. 12. The neutron diffraction pattern of the amorphous $\operatorname{Pr}\left[\mathrm{O}_{3}\right]$

3. Recrystallization temperature $-\mathrm{T}_{\text {recr. }}\left(\geq 210^{\circ} \mathrm{C}\right)$, at which cubic oxide phase of corresponding REM is formed $\left(\mathrm{PrO}_{2-x}\right.$-phases instead of $\operatorname{Pr}(\mathrm{OH})_{3}$ or $\mathrm{La}_{2} \mathrm{O}_{3}$ - phases instead of $\mathrm{La}(\mathrm{OH})_{3}$ (Fig. 14). It is natural to assume that at such a temperature the lattice is abandoned not only by hydrogen atoms, but some part of oxygen atoms. In amorphous phase, at the very first stage, the nucleation centers of face-centered cubic oxide phase are formed (Fig. 13). Further, the oxide $\mathrm{La}_{2} \mathrm{O}_{3}$ - phase intensity increases and diffuse reflection intensities decrease demonstrating that the formed oxide phase grows instead of amorphous phase. It is interesting to observe that on the 5-th day after nucleation of the oxide phase, it does not appear in the neutron diffraction patterns. However, one can observe some small diffraction 

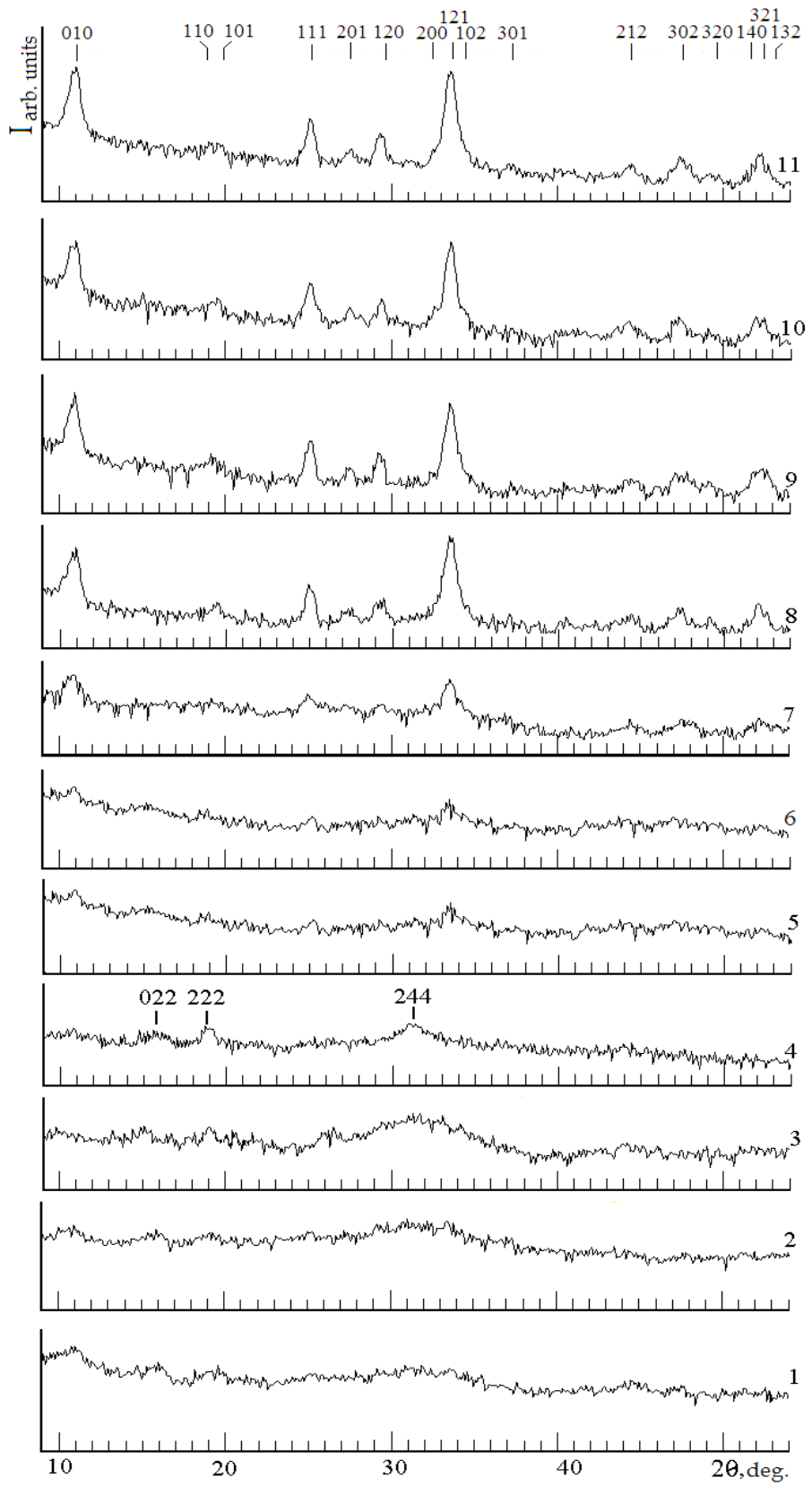

Fig. 13. Neutron diffraction patterns of amorphous $\mathrm{La}\left[\mathrm{O}_{3}\right]$, removed during spontaneous crystallization and its transformation in $\mathrm{La}(\mathrm{OH})_{3}$ : amorphous $\mathrm{La}\left[\mathrm{O}_{3}\right](1)$; after its endurance in atmospheric conditions within 5 (2), 10 (3), 15 (4), 20 (5), 25 (6), 30 (7), 35 (8), 40 (9), 45 (10), 50 (11) days, accordingly. 
peaks of lanthanum trihydrooxide $\mathrm{La}(\mathrm{OH})_{3}$ (Fig. 13-5). These peaks grow in some time, whereas the diffuse reflections decrease and finally disappear (Fig. 13-8, 13-9, 13-10). In the beginning the diffraction peaks of trihydrooxide $\mathrm{La}(\mathrm{OH})_{3}$ are strongly distorted, but finally they acquire ideal form. Thus, duration of processes of spontaneous crystallizationand complete transformation of amorphous $\left.\mathrm{La}_{3} \mathrm{O}_{3}\right]$ into $\mathrm{La}(\mathrm{OH})_{3}$ in atmosphere at temperatures $15-20{ }^{\circ} \mathrm{C}$ is approximately 45-50 days. Certainly, the observed reaction rate depends on air temperature and humidity. The discovered interesting phenomenon consists of spontaneous crystallization of amorphous matter $\left.\mathrm{R}_{0} \mathrm{O}_{3}\right]$, formed by hydrogen thermoemission, and its reverse transformation into trihydrooxide $\mathrm{R}(\mathrm{OH})_{3}$ in normal atmosphere conditions with selective absorption of hydrogen from water molecules and gaseous environment, having hydrogen partial pressure.

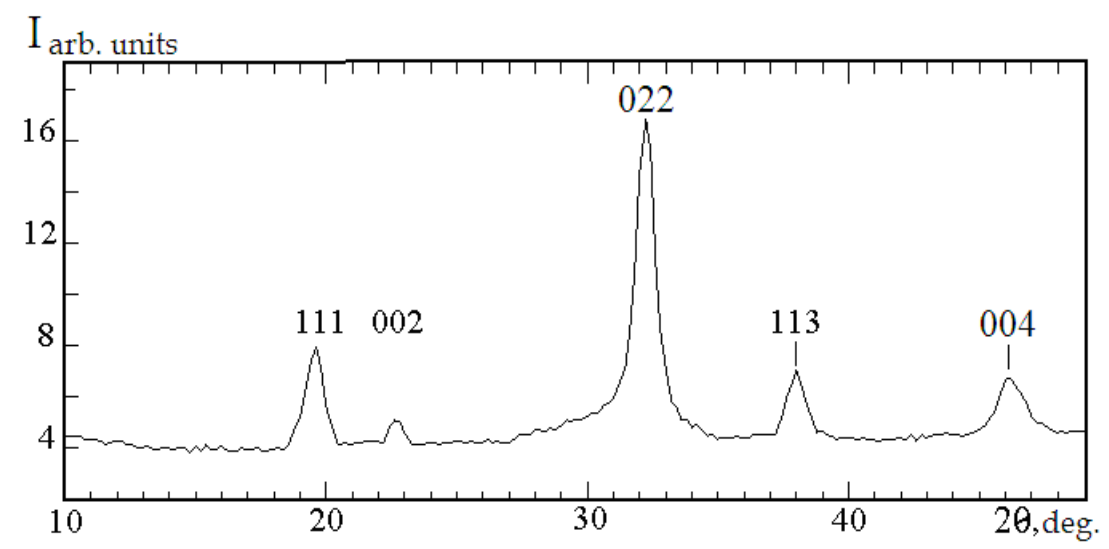

Fig. 14. Neutron diffraction pattern of the cubic $\mathrm{PrO}_{2-x}$ phase.

\section{Low-temperature vacuum evacuation of hydrogen out of crystal lattice of interstitial alloy $\mathrm{TiH}_{2}$}

We have carried out a neutron diffraction study of the phenomenon of hydrogen thermoemission out of a lattice of the cubic phase of titanium dihydride $\mathrm{TiH}_{1.95}$ at temperatures $50 \div$ $250^{\circ} \mathrm{C}$ in continuously pumped out vacuum not worse than $\sim 5,3 \cdot 10^{-3} \mathrm{~Pa}$. An initial sample $\mathrm{TiH}_{1.95}$ has been prepared by direct hydrogenation of a powder of metal by hydrogen at pressure $10^{5} \mathrm{~Pa}$. The purity of initial titanium iodide was $99.98 \%$. For more uniform distribution of hydrogen the samples after saturation were annealed in the pumped out and sealed quartz ampoule during $48 \mathrm{~h}$ at temperature $120^{\circ} \mathrm{C}$. As X-ray diffraction patterns have shown, the obtained sample was single-phase and homogeneous on composition and had face-centered cubic lattice with parameter $a=0.4454 \pm 0.0001 \mathrm{~nm}$. According to the work (Kornilov, 1975), this lattice parameter corresponds to face-centered cubic phase of compound $\mathrm{TiH}_{1,95}$ ( $\delta$-phase). Its processing by Rietveld full-profile analysis confirms the data of the work (Kornilov, 1975): the crystal structure of the cubic phase is described within the framework of space group $\mathrm{Fm} 3 \mathrm{~m}$. Dehydrogenating of $\mathrm{TiH}_{1.95}$ began from the room temperature with a step of $25^{\circ} \mathrm{C}$ and with exposure time at each temperature not less than 24 h. After dehydrogenating neutron diffraction patterns were surveyed at each temperature, 


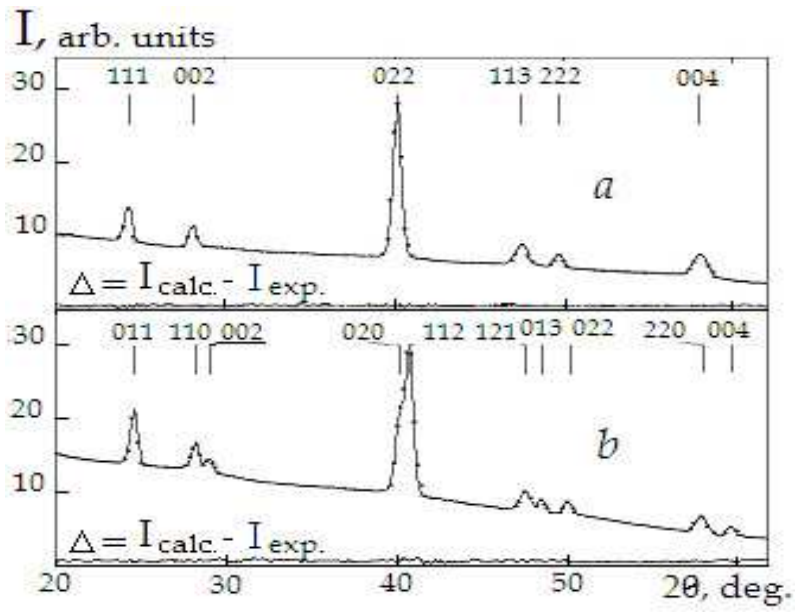

Fig. 15. Neutron diffraction patterns of the sample of titanium hydride $\mathrm{TiH}_{1.95}$ : (a) - initial and (b) - after vacuum thermal treatment at $200^{\circ} \mathrm{C}$. The notations are the same as in Fig. 7.

and content of hydrogen was controlled by neutron diffraction data using both minimization of the R-factors and the relation of intensities of maxima with even (002) and odd (111) Miller indices of the face-centered cubic phase. Up to temperature $100^{\circ} \mathrm{C}$ in diffraction pattern neither qualitative, nor quantitative changes were not found. According to neutron structure analysis, at evacuation of hydrogen in the temperature interval of 100 $175^{\circ} \mathrm{C}$ the decrease of hydrogen concentration from $\mathrm{H} / \mathrm{Ti}=1,84$ up to $1,74( \pm 0,04)$ is observed at practically constant lattice parameter of the initial cubic phase $(a=0.4454 \pm 0.0001 \mathrm{~nm}$ for $\mathrm{TiH}_{1.74}$ ). When evacuating hydrogen at temperature $200^{\circ} \mathrm{C}$ the splitting of some diffraction reflections has been found out (Fig. 15). The analysis of character of splitting showed that cubic lattice of dihydride has transformed to tetragonal. According to X-ray structure analysis, the parameters of the new unit cell were $a=0.3182 \pm 0,0005 ; c=0.4413 \pm 0,0007 \mathrm{~nm}$, degree of tetragonal alteration is $c / a=1,386$. The unit cell parameters of body-centered tetragonal (BCT) phase relate to the initial (cubic) one by the relation: $a_{t} \approx a_{c} / \sqrt{ } 2 ; c_{t} \approx c_{c}$. Similar structure was found for compositions $\mathrm{TiH}_{1.75-2.00}$ (Kornilov, 1975) and also was described in (Bashkin et al., 1993) where it was considered in face-centered tetragonal (FCT) aspect. The recalculation of the parameters received by us for face-centered tetragonal unit cell gives: $a_{F C T}=0.4418 ; c_{F C T}=0.4472 \mathrm{~nm} ; c / a \approx 1.01$. The crystal structure of the bode-centered tetragonal phase is described in the framework of space group $14 / \mathrm{mmm}$. The structure characteristic of the bode-centered tetragonal phase, determined from neutron diffraction data and the divergence factors of structure determination are given in Table 8. Preservation of intense incoherent background in the neutron diffraction pattern testifies that in the lattice there was still a lot of hydrogen. If to increase temperature up to $225^{\circ} \mathrm{C}$, it is observed the significant reduction of incoherent background in the neutron pattern and also a decay of quasistoichiometric face-centered cubic $\mathrm{TiH}_{1.95}$ phase onto nonstoichiometric the FCC cubic $\mathrm{TiH}_{2-x}$ phase and pure Ti. Thus, a change of lattice symmetry occurs before the complete removal of hydrogen; in the $\mathrm{TiH}_{1.95}$, recrystallization is lower than temperature of evacuation: $\mathrm{T}_{\text {recryst }}<\mathrm{T}_{\text {evac }}$ (at vacuum of $\mathrm{P} \approx \sim 5,3 \cdot 10^{-3} \mathrm{~Pa}$ ). The obtained results allow one to 
conclude that vacuum $5,3 \times 10^{-3} \mathrm{~Pa}$ (in which $\mathrm{TiH}_{2}$ dehydrogenating was carried out) is insufficient for removal of hydrogen out of a lattice of metal hydride without a change of crystal symmetry and for obtaining pure titanium with face-centered cubic lattice. For achievement of the given purpose at the temperatures lower than the temperature of recrystallization or decay it is necessary to create high vacuum (about $\sim 10^{-9} \div 10^{-12} \mathrm{~Pa}$ ).

\begin{tabular}{|c|c|c|c|c|c|c|}
\hline $\begin{array}{l}\text { AAto } \\
\text { ms }\end{array}$ & $\begin{array}{l}\text { Number of } \\
\text { atoms }\end{array}$ & Positions & $x / a$ & $y / b$ & $\mathrm{z} / \mathrm{c}$ & $\begin{array}{l}\text { B eff., } \\
\mathrm{nm}^{2}\end{array}$ \\
\hline \multirow[b]{2}{*}{$\mathrm{Ti}$} & \multirow{2}{*}{ 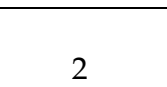 } & \multirow[b]{2}{*}{2 (a) } & 0 & 0 & 0 & \multirow{6}{*}{$\begin{array}{c}0.0041 \pm \\
0,0008\end{array}$} \\
\hline & & & $1 / 2$ & $1 / 2$ & $1 / 2$ & \\
\hline \multirow{4}{*}{$\mathrm{H}$} & \multirow{4}{*}{$3.48 \pm 0,04$} & \multirow{4}{*}{$4(d)$} & 0 & $1 / 2$ & $1 / 4$ & \\
\hline & & & $1 / 2$ & 0 & $1 / 4$ & \\
\hline & & & $1 / 2$ & 0 & $3 / 4$ & \\
\hline & & & 0 & $1 / 2$ & $3 / 4$ & \\
\hline
\end{tabular}

Table 8. Structure characteristics within the framework of space group I4/ $\mathrm{mmm}$ and divergence factors of the bode-centered tetragonal phase of $\mathrm{TiH}_{1.74}$ obtained at the temperature $200^{\circ} \mathrm{C}$ under persistent evacuation.

\section{Discussions}

The formation of observed hydrogen induced phases and phase transitions in metastable state of $\mathrm{Zr}-\mathrm{N}-\mathrm{H}$ system may be explained as follows. Under $375^{\circ} \mathrm{C}$ hydrogen atoms are removed out of the lattice but the configuration of relatively heavy atoms of the matrix does not change. As a result it is possible to obtain the "frozen" structure stabilized previously by hydrogen using thermoemission. At temperatures $450^{\circ} \mathrm{C} \leq \mathrm{T} \leq 650^{\circ} \mathrm{C}$ the diffusive mobility of nitrogen atoms increases, making possible the ordering type change. Further temperature rise causes large displacements of atoms from lattice sites, leads to disorder in distribution of nitrogen atoms. The disordered state occurs typically for oversaturated solid solutions. This state precedes decay process starting above $800^{\circ} \mathrm{C}$. At temperatures below $700^{\circ} \mathrm{C}$ decay process is strongly hindered, as it requires: nitrogen atoms to move at macroscopic distances and the power barrier to be overcome. It is necessary for formation of nucleus of new phase, namely, cubic zirconium nitride. However, ordering process needs only redistribution of nitrogen atoms and their movement at distances about interatomic space. As a result, during low-temperature annealing $\left(400^{\circ} \mathrm{C}<\mathrm{T}<800^{\circ} \mathrm{C}\right)$ the oversaturated solid solution does not decay (that would correspond to a minimum of free energy) instead passes into another ordered or disordered state corresponding to a local minimum. Hence, in solid solutions of nitrogen in $\mathrm{a}-\mathrm{Zr}$, having high decay temperatures, a number of phase transformations in metastable state can be observed at temperatures below $\mathrm{T}_{\text {decay }}$. Fig. 4 shows that depending on the temperature of hydrogen evacuation it is possible to obtain several different phases. The decay temperature for solid solutions $\mathrm{ZrN}_{\mathrm{x}}$ is higher than for $\mathrm{TiN}_{\mathrm{x}}$. Therefore in the $\mathrm{Zr}$ $\mathrm{N}$ system at $\mathrm{T} \leq \mathrm{T}_{\text {decay }}$ it is possible to change the ordering type (anti-CdI $\rightarrow$ anti-CaCl 2 ). It should be noted that isotropic lattice compression takes place in the induced phases where the structure type of initial hydrogenous phase is preserved (Table 9). Thus, during formation of hydrogen-induced phase two observations were made: isotropic compression of the crystal lattice and change of metal atoms displacement directions. Apparently, such 


\begin{tabular}{|c|c|c|c|c|c|c|c|c|c|c|}
\hline \multirow{2}{*}{$\begin{array}{l}\text { Hydroge- } \\
\text { nous phase }\end{array}$} & \multirow{2}{*}{$\begin{array}{l}\text { Sys- } \\
\text { tem }\end{array}$} & \multirow{2}{*}{$\begin{array}{l}\text { Space } \\
\text { group }\end{array}$} & \multicolumn{3}{|c|}{$\begin{array}{l}\text { Before hydrogen } \\
\text { Evacuation }\end{array}$} & \multirow[t]{2}{*}{$\begin{array}{l}\mathrm{T}_{\text {evac., }} \\
{ }^{0} \mathrm{C}\end{array}$} & \multicolumn{4}{|c|}{$\begin{array}{l}\text { After hydrogen } \\
\text { Evacuation }\end{array}$} \\
\hline & & & $a, \mathrm{~nm}$ & $c, \mathrm{~nm}$ & $c / a$ & & $\begin{array}{c}\text { Hydr. } \\
\text { induced } \\
\text { phase }\end{array}$ & $a, \mathrm{~nm}$ & $c, \mathrm{~nm}$ & $c / a$ \\
\hline $\begin{array}{c}\text { Ordered } \\
\operatorname{TiN}_{0,26} \mathrm{H}_{0,15} \\
\end{array}$ & $\mathrm{HCP}$ & $P \overline{3} m 1$ & 0.2978 & 0.4795 & 1.61 & 370 & $\mathrm{Ti}_{2} \mathrm{~N}_{0,52}$ & 0.2956 & 0.4765 & 1.61 \\
\hline $\begin{array}{l}\text { Disordered } \\
\text { TiN }_{0,26} \mathrm{H}_{0,15}\end{array}$ & $\mathrm{HCP}$ & $\mathrm{P}_{3} / \mathrm{mmc}$ & 0.2978 & 0.4795 & 1.61 & 320 & $\mathrm{TiN}_{0,26}$ & 0.2956 & 0.4765 & 1.61 \\
\hline $\mathrm{ZrN}_{0.43} \mathrm{H}_{0,38}$ & $\mathrm{HCP}$ & $P \overline{3} m 1$ & 0.3276 & 0.5324 & 1.63 & 400 & $\mathrm{ZrN}_{0,38}$ & 0.3266 & 0.5299 & 1.63 \\
\hline \multirow{2}{*}{$\mathrm{ZrN}_{0,27} \mathrm{H}_{0,35}$} & $\mathrm{HCP}$ & $P \overline{3} m 1$ & 0.3274 & 0.5240 & 1.60 & \multirow{2}{*}{350} & \multirow{2}{*}{$\mathrm{ZrN}_{0,27}$} & 0.3266 & 0.5226 & 1.60 \\
\hline & $\mathrm{HCP}$ & $P \overline{3} m 1$ & 0.3274 & 0.5332 & 1.62 & & & 0.3270 & 0.5299 & 1.62 \\
\hline $\mathrm{TiC}_{0,38} \mathrm{H}_{0,43}$ & $\mathrm{HCP}$ & $P \overline{3} m 1$ & 0.3024 & 0.4894 & 1.62 & 275 & $\mathrm{Ti}_{2} \mathrm{C}_{0,76}$ & 0.3020 & 0.4990 & 1.62 \\
\hline $\operatorname{Pr}(\mathrm{OH})_{3}$ & $\mathrm{HCP}$ & $\mathrm{P}_{3} / \mathrm{m}$ & 0.6458 & 0.3771 & 0.58 & 150 & $\operatorname{Pr}\left[\mathrm{O}_{3}\right]$ & 0.6580 & 0.381 & 0.58 \\
\hline $\mathrm{TiH}_{1,95}$ & FCC & $F m 3 m$ & 0.4454 & & & 100 & $\mathrm{TiH}_{1,85}$ & 0.4454 & & \\
\hline $\mathrm{TiH}_{1,95}$ & FCC & $F m 3 m$ & 0.4454 & & & 170 & $\mathrm{TiH}_{1,75}$ & 0.4454 & & \\
\hline
\end{tabular}

Table 9. Some structure characteristics of solid solutions before and after hydrogen thermoemission.

effects may be explained by various characters of chemical bond of nitrogen and hydrogen with metal atoms. Hydrogen atoms create isotropic field of elastic stresses resulting in isotropic extension of the structure. One may think that after removing hydrogen atoms isotropic compression of a lattice takes place. According to (Grigorovich \& Sheftel', 1980), chemical bonds in Me-N systems are realized so that nitrogen atoms send a part of valence electrons to the conductivity zone of the metal, and thus nitrogen and metal atoms own common valence electrons. It is obvious that positively charged Me and $\mathrm{N}$ ions repel each other. According to (Geld, 1985), hydrogen atoms are donors as compared to metal atoms. If this is still rue in presence of nitrogen, metal atoms become negatively charged and will be attracted to nitrogen atoms. Hence the direction of displacement for metal atoms in hydrogenous phase will be the opposite to that of metal atoms in hydrogen induced phase. Hydrogen thermoemission in crystals can be explained as relief of potential wells in crystals (Fig. 16). Heavy atoms and hydrogen atoms have different initial wells. Hence to overcome the potential barrier less energy is required for hydrogen compared to heavier atoms.

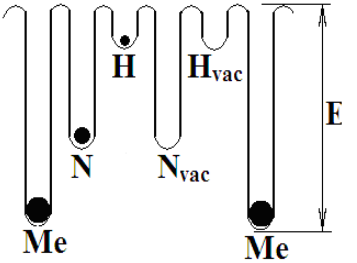

Me is $\mathrm{Ti}$ or $\mathrm{Zr}$

a

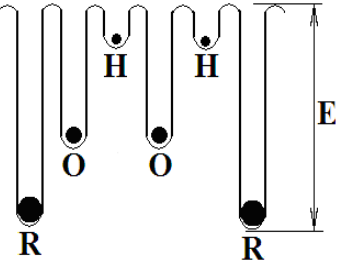

$\mathrm{R}$ is $\mathrm{La}, \mathrm{Nd}, \mathrm{Pr}$

Fig. 16. The relief of potential wells in solid solutions $\mathrm{MeC}(\mathrm{N})_{\mathrm{x}} \mathrm{H}_{\mathrm{y}}(a)$ and in rare earth metal trihydroxides $\mathrm{R}(\mathrm{OH})_{3}(b)$. 


\section{Conclusions}

1. It is found a new phenomenon - complete thermoemission of hydrogen out of a Hcontaining ground crystals which proceeds without altering of crystal symmetry; it is proposed that these artificially-forming metastable phases be named by hydrogen induced phases.

2. At low-temperature $\left(\mathrm{T}=375{ }^{\circ} \mathrm{C}\right)$ high-vacuum evacuations of hydrogen out of lattice of the solid solution $\mathrm{ZrN}_{0.43} \mathrm{H}_{0.38}$ the new, hydrogen-induced $\alpha^{\prime}-\mathrm{Zr}_{2} \mathrm{~N}_{0.86}$ phase was obtained that is absent in the phase diagram of $\mathrm{Zr}-\mathrm{N}$ system; it is impossible to obtain it by traditional methods.

3. During formation of hydrogen induced phase two observations are made: isotropic compression of the crystal lattice and change for metal atoms displacement directions. Apparently, such effects may be explained by various characters of chemical bond of nitrogen and hydrogen with metal atoms.

4. At rise in temperature of $\mathrm{H}$ evacuation two more modifications of the same compound $\left(\mathrm{Zr}_{2} \mathrm{N0}_{.86}\right)$ were obtained but they have somewhat different structure: at $\mathrm{T}=450-650{ }^{\circ} \mathrm{C}$ it is the orthorhombic ordered $\alpha^{\prime \prime}$ phase (sp. gr. Pnnm); at T $=750-800{ }^{\circ} \mathrm{C}-$ disordered hexagonal $\alpha$ phase (sp. gr. $\mathrm{P}_{3} / \mathrm{mmc}$ ). All the three modifications: $\alpha^{\prime}, \alpha^{\prime \prime}$ and $\alpha$ are genetically connected to the initial phase but do not contain hydrogen. Between the found modifications there are reversible and nonreversible phase transitions; conditions and schemes of the transitions are presented.

5. It is established that it is possible to produce the unique metastable hydrogen induced phases, which do not contain hydrogen but keep the structure of initial phase as "frozen", by means of evacuation of hydrogen out of a lattice of some solid solutions of the $\mathrm{Zr}(\mathrm{Ti})-\mathrm{N}-\mathrm{H}$ system using special regimes of vacuum heat treatment. It shows additional opportunities of obtaining new compounds with defined service characteristics by hydrogenating and dehydrogenating.

6. It has been studied the influence of vacuum thermal treatment on stability of the structure of the solid solutions $\mathrm{TiC}_{0,45} \mathrm{H}_{0,90}, \mathrm{TiC}_{0,45} \mathrm{H}_{0,64}$ and $\mathrm{TiC}_{0.35} \mathrm{H}_{0.43}$. It is shown that the phenomenon of complete thermoemission of hydrogen is observed in $\mathrm{TiC}_{0.35} \mathrm{H}_{0.43}$ at temperature $275^{\circ} \mathrm{C}$ under persistent evacuation not worse than $5.3 \times 10^{-3} \mathrm{~Pa}$. In other solid solutions (with the large concentrations of carbon and hydrogen), starting since the same temperature, the decay of the solid solution is observed, a - Ti and FCC titanium carbohydride $\mathrm{TiC}_{x} \mathrm{H}_{\mathrm{y}}$ being formed. The conclusion is made that in solid solutions $\mathrm{TiC}_{\mathrm{x}} \mathrm{H}_{\mathrm{y}}$ thermoemission of $\mathrm{H}$ is observed only in strongly defective structures in which interaction forces between atoms are weak and also temperature of hydrogen evacuation $T_{\text {evac }}$ is lower than temperature of interstitial atoms redistribution or of recrystallization $T_{\text {recryst }} T_{\text {evac }}<$ $\mathrm{T}_{\text {recryst. }}$

7. The crystal structure of metastable hydrogen induced $\mathrm{Ti}_{2} \mathrm{C}_{0.70}$ phase is strongly distorted what is appeared in large scatter of points in neutron diagram and also in large errors of determination of lattice parameters and great value of divergence factor $R_{B r}$. It is found the effect of changing of direction of matrix atoms displacement relatively to their ideal position after complete thermoemission of hydrogen out of lattice of the solid solution $\mathrm{TiC}_{0.35} \mathrm{H}_{0.43}$; it 
may be explained by change of character of interaction between the atoms after "soft" removal of hydrogen.

8. It is shown that at evacuation of hydrogen out of the lattice of titanium hydride $\mathrm{TiH}_{1.95}$ in the temperature interval of $100-175^{\circ} \mathrm{C}$ in continuously pumped out vacuum the decrease of hydrogen concentration from $\mathrm{H} / \mathrm{Ti}=1,84$ up to $1,74( \pm 0,04)$ is observed at practically constant lattice parameter of the initial cubic phase (sp.gr.Fm3m). So, it is shown the possibility of "soft" regulation of composition of titanium hydride without change of lattice parameter. At temperature $200^{\circ} \mathrm{C}$ the body-centered tetragonal (BCT) phase is formed with the unit cell parameters $\mathrm{a}=0.3182 \pm 0,0005 ; \mathrm{c}=0.4413 \pm 0, \mathrm{o} 007 \mathrm{~nm}$ (space group $\mathrm{I} 4 / \mathrm{mmm})$; starting from the temperature of $225^{\circ} \mathrm{C}$ it is observed the significant reduction in hydrogen content and also a decay of stoichiometric $\mathrm{FCC} \mathrm{TiH}_{1.95}$ - phase onto nonstoichiometric FCC $\mathrm{TiH}_{2-x}$ phase and pure Ti. So, a change of symmetry of the lattice is occurred before complete removal of hydrogen out of lattice of $\mathrm{TiH}_{1.95}$, thereby in $\mathrm{TiH}_{2}$ temperature of recrystallization is lower than temperature of evacuation: $\mathrm{T}_{\text {recryst }}<\mathrm{T}_{\text {evac }}$ at pressure of $5,3 \cdot 10^{-3} \mathrm{~Pa}$ and such vacuum is insufficient for obtaining pure titanium with FCC lattice by means of dehydrogenation.

9. The obtained results on study of the phenomenon of hydrogen thermoemission in the solid solutions $\mathrm{TiC}_{0,45} \mathrm{H}_{0,90}, \mathrm{TiC}_{0,45} \mathrm{H}_{0,64}$ and $\mathrm{TiH}_{1.95}$ allow one to conclude that vacuum $5.3 \cdot 10^{-3}$ $\mathrm{Pa}$ (in which their dehydrogenating was carried out) is insufficient for removal of hydrogen out of lattice of these phases without a change of crystal symmetry, and for achievement of the given purpose at the temperatures, lower than the temperature of recrystallization or decay, the higher vacuum is necessary.

10. By neutron diffraction is found that by low-temperature $\left(\mathrm{T}_{\text {эвакуации }}=130-150{ }^{\circ} \mathrm{C}\right)$ removal of hydrogen (by thermoemission) from rare earth metal trihydrooxide $\mathrm{R}(\mathrm{OH})_{3}$ (were $\mathrm{R}$ is $\mathrm{La}$, Pr or $\mathrm{Nd}$ ) under continuous high vacuum evacuating, makes possible to obtain metastable "trioxide" $\mathrm{R}[\mathrm{O}]_{3}$ of radical type. Existence of such substance contradicts to the valence law (oxygen is bivalent and Pr is trivalent in hydroxides). Such "trioxide" have a superfluous negative charge: $\mathrm{Pr}^{3+}\left[\mathrm{O}_{3}\right]^{6-}$. So they aspire "to capture" three more protons (hydrogen ions) from a water molecule. Obviously, this substance can be stable at low temperatures and in the mediums, which are not containing hydrogen. In the air at room temperature this substance, most likely, interacting with water molecules, gradually again turns into trihydroxide $\operatorname{Pr}(\mathrm{OH})_{3}$, compensating the superfluous negative charge by three hydrogen atoms: . From this it follows that substance $\operatorname{Pr}\left[\mathrm{O}_{3}\right]$ can simultaneously be an absorber of hydrogen and generator of oxygen at atmospheric conditions and in any mediums which contains water molecules, without any prior processing like heating or high pressure:

$$
4 \mathrm{Pr}[\mathrm{O}]_{3}(\text { metastable powder crystal })+6 \mathrm{H}_{2} \mathrm{O}=4 \mathrm{Pr}(\mathrm{OH})_{3}(\text { stable powder crystal }) \rightarrow 3 \mathrm{O}_{2} \uparrow
$$

Thus, the obtained material, without any prior processing like heating or high pressure, can be simultaneously oxygen generator and hydrogen accumulator in any mediums. Characteristics of $\operatorname{Pr}\left[\mathrm{O}_{3}\right]$ to transform into stable form $\operatorname{Pr}(\mathrm{OH})_{3}$ by selective bonding of hydrogen from the hydrogen-containing environment allows implication of $\operatorname{Pr}\left[\mathrm{O}_{3}\right]$ as the hydrogen selective absorber. The cycle described can be accomplished many times. 
11. Hydrogen thermoemission is a new method of production for new metastable crystal phases of inorganic compounds which are not observed in phase diagrams and cannot be obtained by conventional methods (quenching, annealing, irradiation, chemical reactions, etc.). Hydrogen is used as a factor of the external system. Comparison of structural peculiarities of hydrogen-induced and corresponding hydrogenous phases opens new sides in understanding of crystal-chemistry of these compounds and crystal-chemical behavior of hydrogen. With such a great variety of hydrogenous inorganic compounds, the clear possibility exists to discover many new metastable crystal phases and materials with new properties that have yet to be explored.

\section{References}

Bacon, G. E. (1975). Neutron Diffraction. Oxford: Clarendon Press, 3rd ed. England.

Bashkin, I. O., Djyueva, 1, M., Lityagina, L. M., Malyshev B. Yu. (1993). Concentration dependence of lattice parameter of $\mathrm{TiH}_{2}$. Fizika tverdogo tela. Vol. 35, No 11. (December 1993), PP. 3104-3114, ISSN 0042-1294.

Geld P. V. \& Ryabov P. A. (1985). Mokhracheva L. P. Hydrogen and physical properties of metals and alloys. Moscow: Metallurgiya, Russia.

Gusev, A. I. (2001). Order-disorder transformations and phase equilibrium in strongly nonstoichiometric compounds. Uspekhi fizicheskikh nauk. Vol. 170, No 1. (January 2001), pp. 3-40, ISSN 0042-1294.

Grigorovich, V. K. \& Sheftel', E. N. (1980). Dispersion hardening of refractory metals. Moscow: Nauka, Russia.

Khidirov, I. (2011). Study of the phenomenon of hydrogen thermoemission from crystal lattice of the trihydroxide $\operatorname{Pr}(\mathrm{OH})_{3}$ by neutron diffraction. International Scientific Journal for Alternative Energy and Ecology, No 5, (June 2011), pp. 19-22, ISSN 16088298.

Khidirov, I., Kurbanov, I. I. \& Makhmudov, A. Sh. (1991). Hydrogen induced metastable phase in the Ti-N system. Metallofizika, Vol. 13, No 6, (June 1991), pp.43-47, ISSN 1024-1809.

Khidirov I., Mirzaev, B. B., Mukhtarova N. N., Bagolepov V. A., Savenko A. F., Pishuk V. K. (2008). Influence of vacuum thermal treatment on structure of solid solutioins $\mathrm{TiC}_{\mathrm{x}} \mathrm{H}_{\mathrm{y}}$. In the Book Carbon Nanomaterials in Clean Energy hydrogen Systems. Pp. 679686, ISBN 978-1-4020-8896, Dordrecht: Springer, The Netherlands.

Khidirov, I. \&, Om, V. T. (1993). Localization of hydrogen Atoms in Rare Earth Metal Trihydroxides $\mathrm{R}(\mathrm{OH})_{3}$. Physica Status Solidi (a), Vol. 140, (September 1993), pp. K59K62, ISSN 1862-6300.

Khidirov, I., Veziroglu, T. N. \& Veziroglu A. (2009). Phase transitions in oversaturated solid solution of nitrogen in the $\alpha-\mathrm{Zr}$ obtained by using hydrogen termoemission. International Scientific Journal for Alternative Energy and Ecology, No 2, (February 2009), pp. 8-14, ISSN 1608-8298.

Kornilov, I. I.(1975). Titan. Moscow: Nauka, Russia.

Portnoy, K. B. \& Timofeeva, N. I. (1986). Oxygen connection of rare-earth metals. Moscow: Metallurgiya. Russia. 
Rietvild, H. M. (1969). Profile Refinement method for nuclear and magnetic structures.Journal of Applied Crystallography,Vol. 2, part 2, (June 1969), pp. 65-71, ISSN 0021-8898.

Schubert, K. (1971). Crystal structures of two-componental phases. Moscow: Metallurgiya, translation from the German language, Russia.

Young, R. A., Wilas, D. B. (1982). Profile Scope Functions in Rietveld Refinements. Journal of Applied Crystallography,Vol. 2, (February 1982), pp. 65-71, ISSN 0021-8898. 


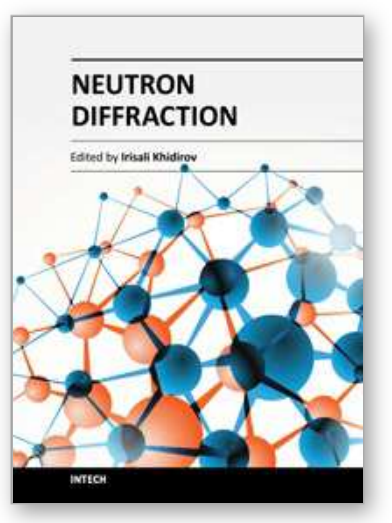

\author{
Neutron Diffraction \\ Edited by Prof. Irisali Khidirov
}

ISBN 978-953-51-0307-3

Hard cover, 286 pages

Publisher InTech

Published online 14, March, 2012

Published in print edition March, 2012

Now neutron diffraction is widely applied for the research of crystal, magnetic structure and internal stress of crystalline materials of various classes, including nanocrystalls. In the present book, we make practically short excursion to modern state of neutron diffraction researches of crystal materials of various classes. The book contains a helpful information on a modern state of neutron diffraction researches of crystals for the broad specialists interested in studying crystals and purposeful regulation of their service characteristics, since the crystal structure, basically, defines their physical and mechanical properties. Some chapters of the book have methodical character that can be useful to scientists, interested in possibilities of neutron diffraction. We hope, that results of last years presented in the book, can be a push to new ideas in studying of crystalline, magnetic structure and a macrostructure of usual crystal materials and nanocrystals. In turn, it can promote working out of new materials with new improved service characteristics and to origin of innovative ideas.

\title{
How to reference
}

In order to correctly reference this scholarly work, feel free to copy and paste the following:

I. Khidirov (2012). Neutron Diffraction Study of Hydrogen Thermoemission Phenomenon from Powder Crystals, Neutron Diffraction, Prof. Irisali Khidirov (Ed.), ISBN: 978-953-51-0307-3, InTech, Available from: http://www.intechopen.com/books/neutron-diffraction/neutron-diffraction-study-of-hydrogen-thermoemissionphenomenon-from-powder-crystals

\section{INTECH}

open science | open minds

\author{
InTech Europe \\ University Campus STeP Ri \\ Slavka Krautzeka 83/A \\ 51000 Rijeka, Croatia \\ Phone: +385 (51) 770447 \\ Fax: +385 (51) 686166 \\ www.intechopen.com
}

\author{
InTech China \\ Unit 405, Office Block, Hotel Equatorial Shanghai \\ No.65, Yan An Road (West), Shanghai, 200040, China \\ 中国上海市延安西路65号上海国际贵都大饭店办公楼 405 单元 \\ Phone: +86-21-62489820 \\ Fax: $+86-21-62489821$
}


(C) 2012 The Author(s). Licensee IntechOpen. This is an open access article distributed under the terms of the Creative Commons Attribution 3.0 License, which permits unrestricted use, distribution, and reproduction in any medium, provided the original work is properly cited. 